National Program for Management of Commercial High-Level Nuclear Waste

\title{
Report \\ on \\ Geologic Exploration Activities
}

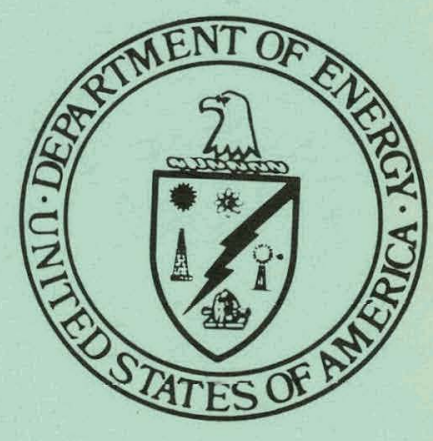

January 1980 


\section{DISCLAIMER}

This report was prepared as an account of work sponsored by an agency of the United States Government. Neither the United States Government nor any agency Thereof, nor any of their employees, makes any warranty, express or implied, or assumes any legal liability or responsibility for the accuracy, completeness, or usefulness of any information, apparatus, product, or process disclosed, or represents that its use would not infringe privately owned rights. Reference herein to any specific commercial product, process, or service by trade name, trademark, manufacturer, or otherwise does not necessarily constitute or imply its endorsement, recommendation, or favoring by the United States Government or any agency thereof. The views and opinions of authors expressed herein do not necessarily state or reflect those of the United States Government or any agency thereof. 


\section{DISCLAIMER}

Portions of this document may be illegible in electronic image products. Images are produced from the best available original document. 


\section{NOTICE}

This report was prepared as an account of work sponsored by the United States Government. Neither the United States nor the Department of Energy, nor any of their employees, nor any of their contractors, subcontractors, or their employees, makes any warranty, expressed or implied, or assumes any legal liability or responsibility for the accuracy, completeness, or usefulness of any information, apparatus, product, or process disclosed, or represent that its use would not infringe privately owned rights. 
DOE-RL-C-14

UC -70

\section{National Program for Management of Commercial High-Level Nuclear Waste \\ REPORT ON GEOLOGIC EXPLORATION ACTIVITIES}

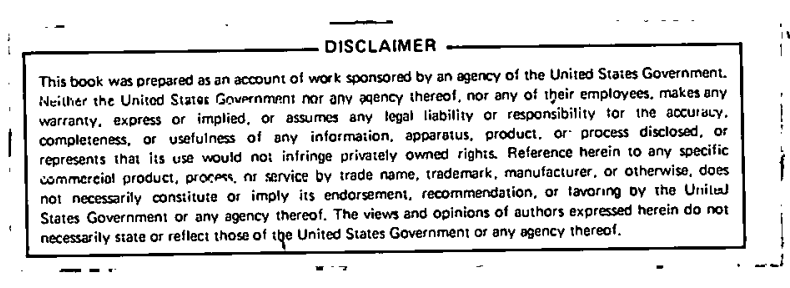

January, 1980

Richl and Operations Office Columbus Program Office Department of Energy 


\section{ACKNOWLEDGMENT}

This report was prepared for the Columbus Program office (RL-C), Richland Operations Office (RL), U.S. Department of Energy (DOE), by the Office of Nuclear Waste Isolation (ONWI), Battelle Memorial Institute, Columbus, Ohio, under Contract EY-76-C-06-1830. The document was compiled by J. Breslin, R. B. Laughon, R. J. Hall, and J. W. Voss of the ONWI staff and incorporates information regarding the Nevada Nuclear Waste Storage Investigations (NNWSI) provided by R. C. Lincoln; Sandia Laboratories, Albuquerque, New Mexico, and information regarding the Basalt Waste Isolation Project (BWIP) provided by G. C. Evans, Rockwell Hanford Operations, Richland, Washington. Review and comments on the document were provided by Don Vieth, DOE-HQ, Phil ip Van Loan, DOE-RL-C, and Colin Heath, DOE-HQ. 


\section{ABSTRACT}

This report provides an overview of the geological exploration activities being carried out as part of the National Waste Terminal Storage (NWTS) Program, which has been established by the U.S. Department of Energy (DOE) to develop the technology and provide the facilities for the safe, environmentally acceptable isolation of civilian high-level and transuranic nuclear wastes, including spent fuel elements, for which the Federal government is responsible. The principal programmatic emphasis is on disposal in mined geologic repositories. Explorations are being conducted or $\mathrm{planned}$ in various parts of the country to identify potential sites for such repositories. The work is being undertaken by three separate but coordinated NWTS project elements. Under the Basalt Waste Isolation Project (BWIP), basalt formations underlying DOE's Hanford Reservation are being investigated. Granite, tuff, and shale formations at the DOE Nevada Test Site (NTS) are being similarly studied in the Nevada Nuclear Waste Storage Investigations (NNWSI). The Office of Nuclear Waste Isolation (ONWI) is investigating domed salt formations in several Gulf Coast states and bedded salt formations in Utah and Texas. The ONWI siting studies are being expanded to include areas overlying crystalline rocks, shales, and other geohydrologic systems. The current status of these NWTS efforts, including the projected budgets for FY 1981, is summarized, and the criteria and methodology being employed in the explorations are described. The consistency of the overall effort with the recommendations presented in the Report to the President by the Interagency Review Group on Nuclear Waste Management (IRG), as well as with documents representing the national technical consensus, is discussed. 


\section{TABLE OF CONTENTS}

Page

1. INTRODUCTION 1

1.1 Purpose of This Report 1

1.2 Organization of This Report 2

2. THE DOE COMMERCial WASTE MANAGEMENT PROGRAM 3

2.1 Objective and Organization 3

2.2 The NWTS Program. 4

2.2.1 Bas is fur Emphas is on Geologic Isolation 4

2.2.2 Technical Approach 10

2.2.3 Implementation of the NWTS Geologic Isolation 10

Program

3. THE DOE/NHTS GEOLOGICAL EXPLORATION PROGRAM 17

3.1 Criteria Employed in Repository Site Selection 17

3.2 Methodology Employed in NWTS Geologic Explorations 26

3.2.1 General Approach 26

3.2.2 Site Screening Process 32

3.2.2.1 Identification of Formations of Interest 33

3.2.2.2 Regional Reconnalssance Surveys 33

3.2.2.3 Area Studies 34

3.2.2.4 Detailed Confirmation Studies 35

3.3 Current and Planned Exploration Efforts 37

3.3.1 Basalt Waste Isolation Project (BWIP) 39

3.3.2 Nevada Nuclear Waste Storage Investigations (NNWSI) 41

3.3.3 National Program (ONWI) 43

3.4 Proposed FY 1981 Budget for NWTS Site Screening 53

Activities

3.4.1 BWIP 53

3.4.2 NNWSI 55

3.4.3 ONWI 55

3.4.3.1 Salt 55

3.4.3.2 Argillaceous and Crystalline Media $\quad 55$

3.5 Relation of the Site Screening Program to the IRG 55

Recommendations

3.5.1 A Systems Approach Should be Stressed 56

3.5.2 A Number of Different Sites in Various Types 57

of Rock Formations Should be Evaluated

3.5.3 Planning Should be In Full Compliance with NEPA 60

3.5.4 A Social Consensus Must be Obtained; A State 61

Planning Council Should be Formed

4. REFERENCES

64

APPENDIX 


\section{LIST OF TABLES}

Page

Table 3.1. Proposed NWTS Generic Site-Qualification Criteria 21

Table 3.2. Examples of Factors Studied in Meeting NWTS 22

Generic Site-Qualification Critera

Table 3.3. Examples of Factors and Specifications Used in : 23

Regional Screening of Bedded Salt

Table 3:4. Example of Geological Field-Activity Matrix

Table 3.5. Status of NWTS Geologic Exploration Efforts

38

Table 3.6. Proposed FY 1981 Budget (Millions) for NWTS Site Screening Activities

\section{LIST OF FIGURES}

Figure 2-1. Technical Structure of the NWTS Program 11

Figure 2-2. Geologic Disposal System 12

Figure 2-3. The Multibarrier Concept Applied to Nuclear Waste 13

Figure 2-4. NWTS Geologic Repository Program Management · $\quad 15$

Figure 3-1. NWTS Site Qualification/Selection Methodology 27

Figure 3-2. Location Map: Outcrop Extent of Columbia River 40 Basalt Group, Pasco Basin, and Hanford Site

Figure 3-3. Map of Nevada. Test Site 42

Figure 3-4. Salt Basins Being Investigated for Terminal Storage 44 of Radioactive Wastes

Figure 3-5. Map of Salina Study Regions in New York and Ohio 


\section{INTRODUCTION}

\subsection{Purpose of This Report}

As part of the National Waste Terminal Storage (NWTS) Program the U.S. Department of Energy (DOE) is conducting geologic explorations in various sections of the United States for the purpose of identifying potential sites for the safe, long-term isolation of commercially generated high-level waste (HLW) and transuranic waste (TRU) in mined geologic repositories.

There are many geologic formations within the continental United States that may offer potential sites for repositories, and some of these formations are currently under investigation in the DOE exploration program. The selection of the site for the first NWTS repository will occur only after a number of potential sites have been identified through a technically conservative, step-by-step screening process. This process is expected to require a number of years.

The DOE repository-site screening activities are open to public and peer review and comment. No exploration work is undertaken in a given State prior to consultation with the state agencies concerned. The information developed at each stage of the site-screening process will be made available for public and peer review and comment. Finally, since all NWTS repositories will be licensed by the Nuclear Regulatory Commission (NRC), DOE's selection of a proposed site will come under intense technical and environmental review by the NRC and other interested government agencies dedicated to the preservation of public health and safety.

This report is intended to provide the public with a concise. overview of the current status (December, 1979) of all DOE geologic exploration activities associated with the NWTS site-screening effort. It summarizes current and $\mathrm{planned}$ exploration work and discusses the criteria, methodology, and technical and institutional guidance being applied. It includes a reference list of documents containing more detailed technical information. Public comment on this document, or on the exploration program, is welcomed. 


\subsection{Organization of This Report}

The text of this report is organized into two major sections. The first provides a brief overview of the DOE commercial waste management effort and of its principal programmatic implementation under the National. Waste Terminal Storage (NWTS) Program. The basis for the concentration in the NWTS Program on geologic isolation, particularly with reference to the recommendations of the Interagency Review Group on Nuclear Waste Management is explained and the approach being employed in the implementation of the NWTS effort is outlined.

The second major section focuses on the NWTS geologic exploration activities. The criteria that will ultimately be applied across the program in the qualification and selection of specific repository sites are detailed. The methodology of the site screening process is explained. The status of the current and $\mathrm{planned}$ exploration efforts is summarized as well as the funding requirements associated with them. Efforts to implement those IRG recommendations which impact the geological exploration process are described al so.

A reference list identifying the documents employed in the preparation of this report is provided.

The geological exploration effort is a complex undertaking and one that is being continually refined in response to emerging technical and institutional issues. The effort is supported by an elaborate technology program involving laboratory and field testing as well as the development of comprehensive analytical models for understanding and predicting the performance of a repository and its associated hydrogeological systems. These aspects of the exploration effort can only be alluded to in this brief report. 


\section{THE DOE COMMERCIAL WASTE MANAGEMENT PROGRAM}

\subsection{Objective and Organization}

The objective of the $U$. S. nuclear waste management program is to effectively isolate from the biosphere existing and future nuclear wastes from military and civilian activities until such time as they no longer pose a significant threat to public health and safety. Under the provisions of the Atomic Energy Act of 1954, the Energy Reorganization Act of 1974, and the Department of Energy Organization Act of 1977, the responsibility for defining and implementing this national waste management effort is assigned to the Department of Energy (DOE). The Environmental Protection Agency (EPA) and the Nuclear Regulatory Commission (NRC) are responsible for providing a framework of criteria, standards, and regulations that will assure that the disposal procedures for commercially generated wastes developed and implemented by DOE are consistent with the achievement of the goal of safe, long-term isolation.

Within DOE, the responsibility for planning and implementation of the national waste management effort resides with the Office of Nuclear Waste Management (ONWM). The effort involves three major activities: the Defense Waste Management Program, the Spent Fuel Storage Program, and the Commercial Waste Management Program. Since the commercial and defense waste management efforts of ten deal with similar waste forms and waste-handling technologies, the two activities are $p l$ anned and managed jointly to complement each other and avoid duplication of effort. Basic R\&D is funded with civilian or defense budgets on the basis of where the first or most widespread application of the data sought will occur. Applied work, such as the adaptation of existing equipment and processes, is funded by the program that will use the technology.

Responsibility for day-to-day administration of the waste management program within the guidelines established by the Office of Nuclear Waste Management resides with various DOE field offices. Actual performance of the work is carried out by a large number of appropriately qualified DOE contractors that are selected and monitored by the field offices in 
accordance with ONWM-approved program plans, schedules, and budgets. The limited number of people/organizations possessing expertise in some of the technologies being applied in the work constrains the scheduling of the program.

\subsection{The NHTS Program}

The major programmatic effort in the commercial waste management activity is the National Waste Terminal Storage (NWTS) Program. The objective of the NWTS Program is to develop the technology and provide the facilities for the safe, environmentally acceptable isolation of civilian high-level and transuranic nuclear wastes, including spent fuel elements from the once-through nuclear fuel cycle, for which the Federal government is responsible. Although alternative methods are being studied, the principal programmatic emphasis is on disposal of these wastes by. emplacement in deep, stable, geologic formations.

\subsubsection{Bas is for Emphasis on Geologic Waste Isolations}

The possibility of securing safe waste isolation in geologic repositories has been under study for many years, and there is now widespread agreement among informed scientists in this country and abroad concerning the general technical feasibility of the concept. However, there are numerous technical issues that remain unresolved. Moreover, the disposal of nuclear waste is a national problem and one that, ultimately, must be solved on the basis of not only a technical consensus but a positive national political and social consensus regarding the safety and environmental acceptability of the method used.

The planning and implementation of the NWTS geologic repository program, therefore, must be conducted in a manner that adequately addresses political and social concerns, as well as technical issues. Three documents furnish baseline policy and technical guidance for the definition of a program consistent with the achievement of this objective: 
(1) "Report to the President by the Interagency Review Group on Nuclear Waste Management" (IRG report)(1) (2). "Draft-Environmental Impact Statement Management of Commercially
Generated Radioactive Wastes" (DEIS) (2)

(3) "Earth Science Technical Plan for Mined Geologic Disposal of Radioactive Waste" (ESTP) $(3)$.

The IRG report states that the primary objective of waste management is that

Existing and future nuclear waste from military and civilian activities

(including discarded spent fuel from the once-through nuclear fuel

cycle) should be isolated from the biosphere and pose no significant

threat to public health and safety.

Six candidate technologies for the ultimate disposal of high-level and transuranic wastes were examined by the IRG:

- Geologic disposal' in mined repositories

- Disposar in deep ocean sediments

- Disposal in very deep drill holes

- Rock-melting concept

- Partitioning of reprocessing waste, transmutation of heavy radionuclides, and geologic disposal of fission products

- Ejection into space.

The IRG concluded that, of the six options, geologic disposal in a mined repository will be available earlier than any of the others. The IRG therefore recommended that "...near-term program activities should be predicated on the tentative assumption made for interim planning purposes that the first disposal facilities will be mined repositories."

The IRG Staff Subgroup on Alternative Technologies defined and evaluated four technical strategies for the geologic disposal of high-level waste as illustrating a range of possible approaches:

- Strategy I provides that only mined repositories would be considered and that only geological environments with salt as the emplacement medium would be considered for the first several 
repositories. As a result of past focusing on salt, there is a large volume of information available. In addition, one body of opinion holds that salt is the best, or at least an acceptable, emplacement medium and that suitable sites can be found where salt is the host rock.

- Strategy II provides that, for the first few facilities, only mined repositories would be considered. A choice of site for the first repository would be made from among whatever types of environments have been adequately characterized at the time of choice. Because generic understanding of engineering features of a salt repository are the most advanced, the first choice is expected to be made from environments based on salt geology. Sites from a wider range of geologic environments would be available for selection somewhat later.

- Strategy III provides that, for the first facility, only mined repositories would be considered. However, three to five geological environments possessing a wide variety of emplacement media would be examined before selection was made. 0ther technological options would be contenders as soon as they have been shown to be technologically sound and economically feasible.

- Strategy IV provides that the choice of technical options and, if appropriate, geological environment be made only after information about a number of environments and other technical options has been obtained.

The strategy to be used in the NWTS Program will be determined by the President and the Congress. Currently, the assumptions in the NWTS Program are consistent with site selection in the mid-1980's and repository operation in the 1990's. However, the program supports the development of the capability to implement each of the four IRG options.

Among the recommendations made to the President by the IRG are the following:

(1) A systems approach should be used to select the geologic environment, repository site, and waste form.

(2) Detailed studies of specific potential repository sites in different geologic environments should begin immediately; present scientific and technical knowledge is adequate to identify potential repository sites for further investigation. 
(3) The degree of long-term isolation provided by a repository can be assessed only through analytical modeling.

(4) The choice of strategies for the disposal of high-level waste and their implementation must await completion of the appropriate generic environmental impact statement required by the National Environmental Policy Act.

(5) A number of potential sites in a variety of geologic environments should be identified and steps taken to reserve the option to use them. Near-term options should create the option of at least two (or possibly three) repositories becoming operational within this century, ideally and insofar as technical and other considerations permit, in different regions.

(6) A-repository should begin operations in a technically conservative manner.

(7) Construction and operation of a repository should proceed on a stepwise basis.

(8) Initial emplacement of waste in at least the first repository should permit retrievability of the waste for some initial period of time.

(9) A State Planning Council should be formed, to be appointed by the President, to provide state and local perspectives in the development and recommendations for a comprehensive national nuclear waste management plan.

(10) A social consensus must be obtained and public knowledge of the program expanded and public interaction encouraged.

These IRG recommendations are currently under review by the President.

The DEIS, which was recently issued and is undergoing public review, considered 10 alternative waste disposal options:

- Geologic disposal in mined repositories

- Chemical resynthesis

- Disposal in very deep drill holes.

- Rock-melting concept

- Is land disposal

- Geologic disposal below sea beds

- Disposal in ice sheets 
- Reverse-well disposal

- Partitioning and transmutation

- Space disposal.

The DEIS concluded that detailed development of proposed disposal concepts must address the following issues:

- Properties relevant to isolation or disposal

- Issues needing resolution to determine technical feasibility and environmental impact

- Adequacy of available data base

- Predisposal systems

- Environmental analysis of total system

- Research and development requirements

- A measure of its potential merit on the basis of evaluation criteria.

In terms of technology development and the availability of data for evaluation, disposal in a mined geologic repository was the leading candidate. The concept of conventional geologic disposal is the emplacement of HLW in mined repositories at depths of about 600 meters, the actual depth being a function of the type of rock.

Although numerous geologic media exist, the DEIS examines only salt, basalt, granite, and shale in any detail. These are considered as representative of all geologic media. The DEIS concludes that six general considerations for geologic disposal should be considered in choosing the geologic medium for an actual repository. They are (1) depth of burial, (2) properties and dimensions of the host rock, (3) tectonic stability, (4) hydrologic properties of the host rock, (5) resource values of the host rock, and (6) secondary protection provided by the geologic media surrounding the host rock.

The ESTP classifies the various earth-science research tasks involved in developing geologic repositories for radioactive waste, performed by or on contract for DOE and the U. S. Geological Survey (USGS); shows how 
these tasks address the principal remaining technical problems related to such repositories; and identifies technical questions that require additional attention. The ultimate objective of the ESTP is to recommend future program priorities.

The ESTP was prepared by DOE and USGS through a working group composed of representatives from DOE, DOE contractor organizations, and USGS.

In general, the ESTP assesses the essential data for evaluating the NWTS Program, modifying the current program, improving coordination, and planning future research.

Specifically, the ESTP:

- Presents a systematic review of earth-science questions concerning geologic repositories and recommends research to answer those questions related to site selection, characterization, and evaluation; repository design and operation; and risk assessment.

- Inventories and classifies current research and development activities to facilitate integration and coordination of DOE- and USGS-sponsored work.

- Identifies researich and development activities which should be more closely coordinated for timely resolution of technical questions.

- Specifies technical plans to resolve significant uncertainties regarding mined repositories, such as those discussed in the IRG report and others.

- Provides information that can be used to estimate the time required for resolution of earth-science technical questions and to organize the work and resources to determine a realistic schedule for developing a repository.

- Recommends the preparation of summary documents on key technical problems that will aid in planning future research and development activities.

In summary, both the IRG report and the DEIS evaluate alternative waste-disposal processes and conclude that mined geologic disposal will be available soonest. The IRG report recommends that near-term program activities should be predicated on the tentative assumption that the first disposal facilities will be mined repositories. The DEIS provides a detailed evaluation of ten alternative methods for waste disposal and concludes that the development of radioactive wastes in geologic formations can likely be 
developed and applied with minimal environmental consequences. The ESTP furnishes detailed programmatic guidance for research addressing earth science issues associated with geologic waste disposal. DOE believes that proceeding with mined geologic repositories can be adequately justified by the information contained in these baseline documents.

\subsubsection{Technical Approach}

The technical approach being employed in the NWTS Program (Figure 2-1) involves three major groups of activities:

(1) Criteria development, which supplies the baseline documentation in the development of performance criteria the repository system must satisfy

(2) Mined geologic repository studies, including exploration and technology development, which apply the criteria

(3) Studies of alternative waste isolation concepts.

As shown in Figure 2-2, the geologic repository is conceived as a three-component system (the waste package, the repository, and the site) wherein the safe isolation of nuclear wastes will be assured by a number of natural and man-made barriers between the wastes (emplaced in some host rock about $600 \mathrm{~m}$ below the earth's surface) and the uppermost strata of the earth's surface (the biosphere). These barriers (Figure 2-3) include the waste form itself, the waste packaging, the backfilling and sealing of the emplaced wastes, the host rock immediately surrounding the wastes, the geologic and hydrologic regime surrounding the host rock, and institutional barriers.

\subsubsection{Implementation of the NWTS Geologic Isolation Program}

The scope of the NWTS geologic repository effort, which has been designated a Major Systems Acquisition Project, includes comprehensive geologic exploration, technology development, testing, and design activities, as well as the licensing, construction, operation, and decommissioning of 


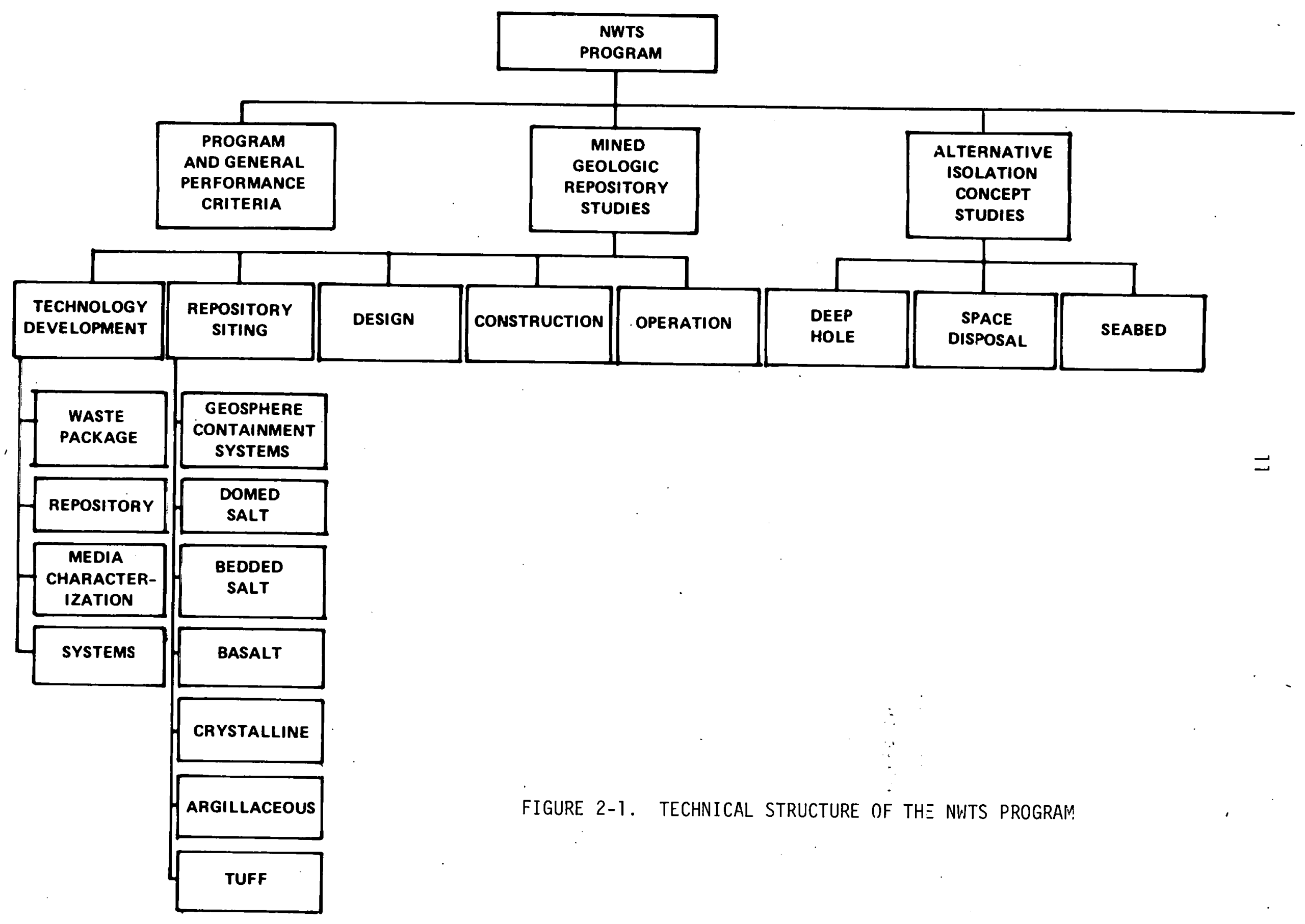




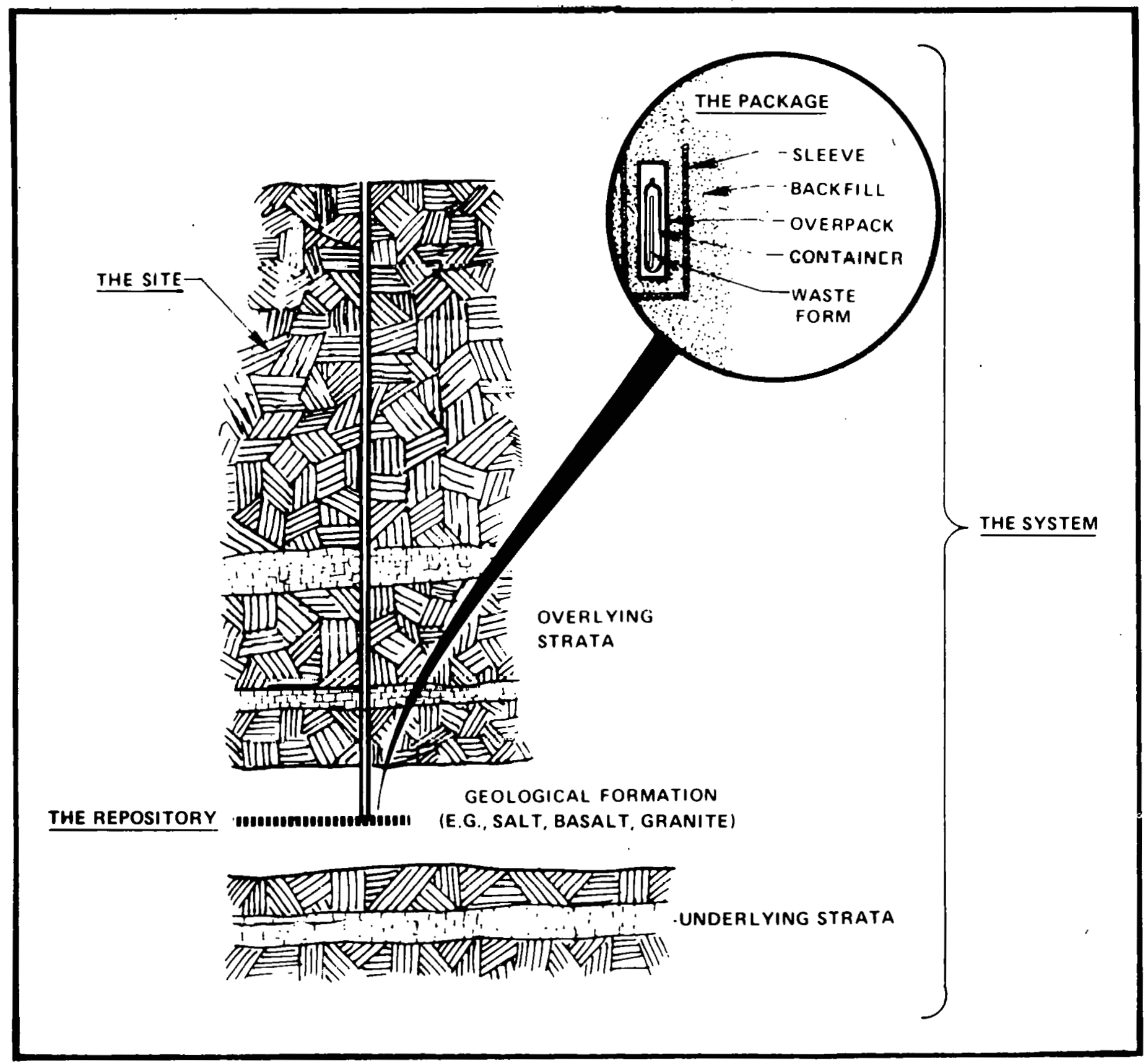

FIGURE 2-2. GEOLOGIC DISPOSAL SYSTEM 


\section{Purpose of Control}

Positive protection for duration of stable governments

Long-lasting indicator of repository existence not uniquely tied to repository site

Long-lasting indicator of repository existance not tied to government stability

Visible on-site warning of repository existence

Indication of repository due to off-normal conditions that would be apparent to future investigators and would curtail further actions

Engineered measures to protect safety of future explorers and public during and for some time after exploration of system

System performance characteristic is designed to protect public if system integrity is decreased by any mechanism

\section{Nature of Control}

Institutional management of activities within site boundaries

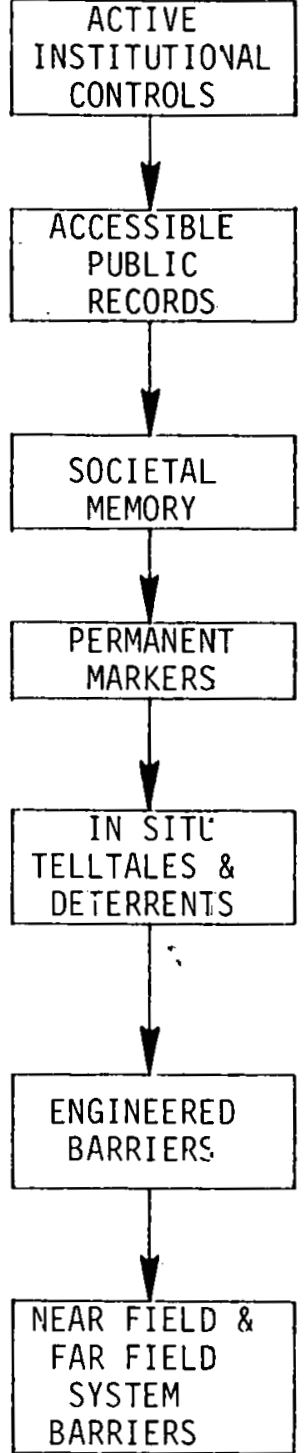

Variety of highly visible, highly durable markers chosen to ensure long survival of one or more markers

Physical and chemical tracers implanted in host rock and system having $\infty$ lifetime until intrusion, long-postintrusion lifetime

Physical and chemical barriers designed to exist throughout intrusion and for longtime thereafter. Essentially $\infty$ preintrusion life expectancy

Repository system chosen to mitigate releases to biosphere regardless of initiating event; i.e., natural or human induces 
geologic repositories and of spent-fuel packaging facilities. The program will be carried out in four phases. Only Phase I is currently active. Ultimately, all four phases will proceed concurrently. The four phases are:

(1) Technology Development Phase. This first phase of the program focuses on identifying potential repository sites, using the systems approach, and developing the technologies and methodologies that will be necessary to design, construct, license, operate, and safely decommission repositories in such a way that will assure the wastes will remain isolated from the biosphere.

(2) Engineering Development Phase. This phase of the work will involve the systematic application of the knowledge and understanding gained from the Phase I research and technology development to carry out the detailed design, licensing, construction, and performance testing of the first repository(ies).

(3) Operations Phase. During this phase, wastes will be emplaced, monitored, and maintained "retrievable" for some period of time. This phase will end with a petition to NRC for approval for repository closure/sealing.

(4) Decommissioning Phase. This final phase will embrace those operations required for the closure/sealing of the repository and the implementation of monitoring plans. This phase will end with the restoration of the surface environment to its near original state, the imposition of long-term institutional controls, and the initiation of any surveillance or monitoring systems which might be desired or required.

During the NWTS Technology Development Phase, the work will be accomplished by three separate, but coordinated, Project Elements: (1) the Office of Nuclear Waste Isolation (ONWI); (2) the Basalt Waste Isolation Project (BWIP); and (3) the Nevada Nuclear Waste Storage Investigations (NNWSI). Each is conducting work in the general areas of site evaluation, technology development, facility design, and field testing specific to certain geologic systems. In addition, ONWI has oversight responsibilities and responsibilities for developing that technology which is generic to the design and safety assessment of mined repositories (Figure 2-4). With respect to site evaluations, BWIP is investigating the potential of the basalt formations underlying DOE's Hanford Reservation; NNWSI is investigating several different media (including granite, tuff, and shale) underlying DOE's Nevada Test Site (NTS); and ONWI is evaluating other 


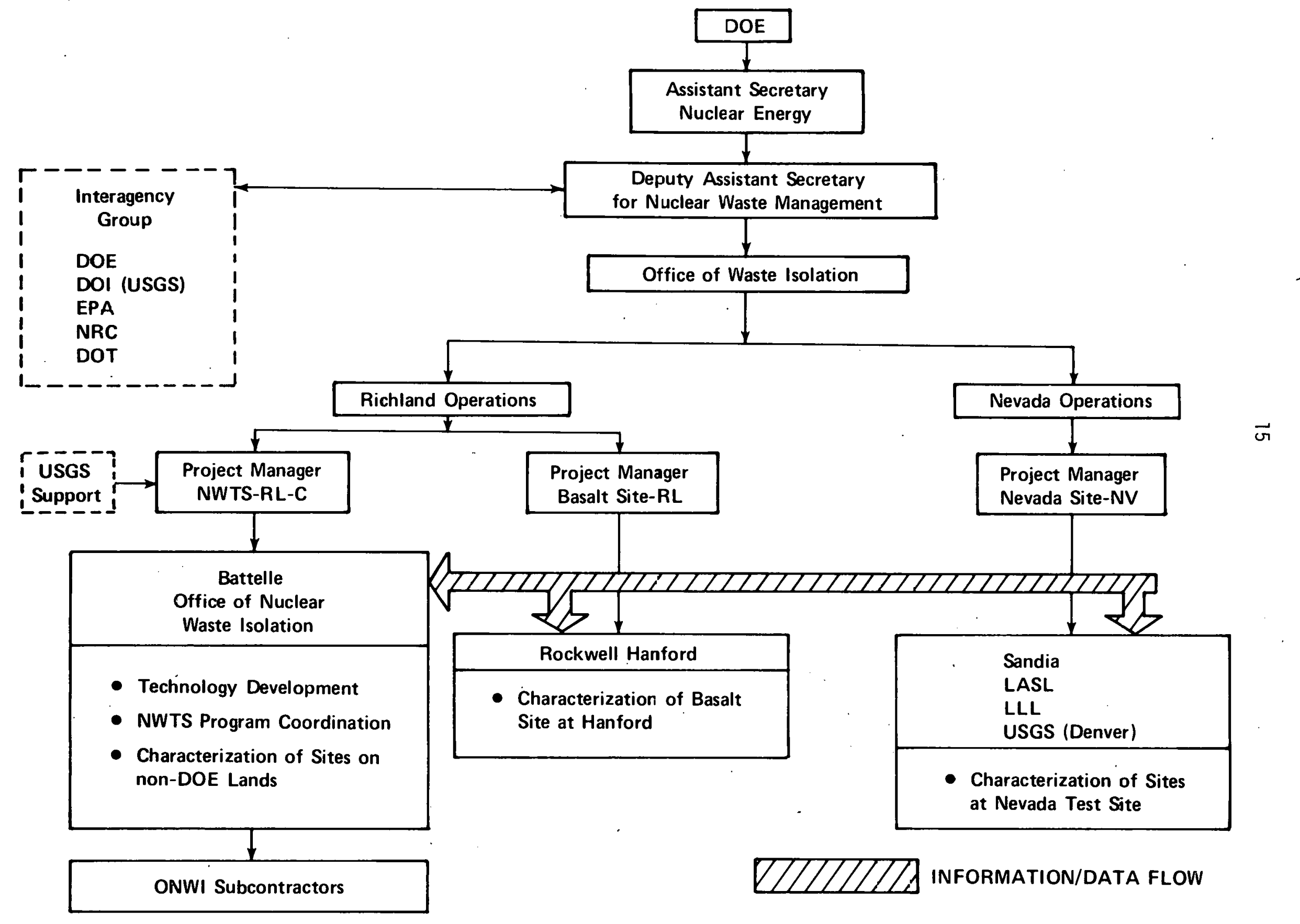

FIGURE 2-4. NWTS GEOLOGIC REPOISITORY PROGRAM MAINGEMEYYT ORGANIZATION 
formations/media within the contiguous United States. The ONWI siting investigations, which have historically focused on the potential of areas overlying salt formations, are being expanded to include areas overlying crystalline rocks, shales, and other hydrogeologic systems consistent with the IRG recommendations.

Each Project Element annually updates its own Technical Program Plan outlining its specific objectives, the manner in which they will be accomplished, and the milestones for their achievement. To supplement these Technical Program Plans for the individual Project Elements, other plans for accomplishing the various tasks which are generally applicable to the Project will be prepared, widely distributed for review and comment, and approved as necessary. Examples are a Siting Plan, a Licensing Plan, a Quality Assurance Program Plan, and the aforementioned Earth Science Technical Plan, each of which will be applicable to the first repository regardless of its location. Other activities worked on collectively include the development of such items as waste package criteria and site qualification/selection criteria.

To assure that all waste management technical issues are identified and are being fully addressed in a timely manner, several independent review groups are being established by ONWI, BWIP, and NNWSI to assist in formulating the detailed work elements of the overall NWTS Program and to provide critical progress reviews.

Because public understanding and informed public participation in the above activities are considered important ingredients to their success, each Project Element has its own Public Information Plan. The ONWI Plan, consistent with its oversight responsibilities, provides also for preparing and disseminating timely factual information to the public at large. 


\section{THE DOE/NWTS GEOLOGIC EXPLORATION PROGRAM}

This section of the report provides an identification of the geologic formations, regions, areas, and potential sites under study by DOE in the repository site-qualification/selection effort being conducted as part of the commercial waste management program. The criteria and methodology being employed in the exploration program as well as the responsiveness of the efforts to pertinent IRG recommendations are briefly described also.

\subsection{Criteria Employed in Repository Site Selection}

As stated earlier, under the provisions of the Energy Reorganization Act of 1974, DOE was assigned responsibility for developing and operating facilities for long-term isolation of high-level nuclear wastes. The NRC was given regulatory responsibility for licensing such facilities. The EPA is developing environmental criteria and accompanying numerical standards which will be used as guides by all Federal agencies, including the NRC, that have responsibility for managing or regulating radioactive wastes. The EPA has published for comment proposed criteria for disposal of nuclear wastes, but has not yet issued the standards that will quantify the acceptable risks. The NRC will prepare, on the basis of the EPA criteria and standards, specific regulations for licensing and regulatory guidance documents needed by DOE in responding to the regulations. The regulations will define NRC's interpretation of the responsibilities under the law, the procedures NRC will use to meet these responsibilities, and the obligations of those subject to regulation ( $D O E)$, as prescribed in enabling legislation. Guidance will be furnished in the form of regulatory guides, staff position papers, and license review $p l a n s$. It should be noted that guidance does not have the force of $1 \mathrm{aw}$. It defines what NRC believes is an acceptable response to the regulations, but it does not preclude other acceptable responses.

The NRC plans to publish these various regulatory documents periodically, as the Commission's policy and technical position are established on the various issues that must be addressed in the licensing process. It will be several years before a complete body of regulations and 
guidance applicable to the licensing of a repository in all geologies is in place.

Although formal regulatory guidance is currently lacking, DOE through interactions with regulatory authorities has been provided information on the forms that the regulations are most likely to take. However; the IRG strategy question and the uncertainty as to what information DOE U1timately will be expected to provide to demonstrate that a proposed geologic repository system will provide adequate and environmentally acceptable waste isolation requires a program of broad flexibility in planning, scheduling and allocation of resources for the lengthy and costly geologic exploration and technology development programs that must precede the application for the construction authorization for the first repository.

Pending resolution of these uncertainties, DOE has taken steps to begin to implement programmatic efforts responding to the IRG recommendations, including acceleration of exploration activities initiated in FY 1979 on alternative geologies in an attempt to minimize the delays ( 3 to 4 years) and expenditures (exploration costs are increasing annually) that will be occasioned in site selection should IRG Strategy III be adopted. Programmatic implementation of other specifics in the IRG recommendations which could impact the repository site-selection program (e.g., development and application of procedures to secure participation and concurrence of the States in siting activities, also initiated in FY 1979) is being accelerated as well. These actions are in consonance with DOE's obligation to provide an early solution to the waste disposal problem and the IRG conclusion that, on the basis of the available technology, emphasis should be placed on geologic isolation.

The Presidential decision on the IRG siting strategy to be employed in the commercial waste management program will, as already suggested, have profound ramifications on the expenditures of time and money that will be incurred in bringing the first proposed site before the NRC. However, regardless of the strategy ultimately-selected, substantial cost and temporal penalties could be incurred if the information developed in the DOE site screening process, in which a selected site is a product of several years of geological and scientific study, were to prove inadequate to meet NRC 
licensing regulations, when they are promulgated, or if DOE delayed implementation of screening activities until the regulations were available. Since the second alternative is impracticable, DOE has undertaken extensive planning efforts to assure that any proposed site identified in DOE's application to NRC for a repository construction authorization will be supported by characterization data adequate to demonstrate compliance with the applicable site performance regulations. Such efforts have included the preparation of licensing $\mathrm{plans,} \mathrm{ER/SAR} \mathrm{format/content} \mathrm{guides,} \mathrm{the} \mathrm{DEIS,} \mathrm{and}$ the ESTP, all of which, in toto, constitute a comprehensive analys is and definition of what information will be required in a licensing action, what portion of that information is currently available, and what information must be developed. The insight obtained has been applied in structuring the NWTS technology development program and in planning the geological explorations. A key element in the latter activity has been the formulation of site-qualification/selection criteria.

The final qualification and selection of a specific repository site will be the culmination of a complex and costly series of technical and nontechnical evaluations and analyses that may require 4 years or more to complete. Through the sequential phases of the study process, regions within formations, areas within regions, locations within areas, and sites within locations are selected or rejected for increasingly detailed evaluations. The last two phases of the four-phase screening process involve comprehensive geologic/hydrologic explorations and environmental studies, as well as supporting laboratory, field testing, and analytical investigations, and require expenditures of tens of millions of dollars.

From the onset of the NWTS program, the decisions to proceed from one phase of the site-qualification/selection process to the next have been made on the basis of conformance with formal project-specific (i.e., BWIP, NNWSI, ONWI) site-qualification/selection criteria designed to permit assessments and comparisons of potential sites involving a given host rock to be made on a consistent, equivalent basis. However, if either IRG Strategy II or Strategy III is implemented in the National repository development effort, the qualification/selection criteria should also permit such assessments and relative comparisons to be made of potential sites involving 
any of the various host rocks of interest now or in the future in the NWTS program. Efforts to define such program-wide site qualification/selection criteria are now well advanced. Ten basic criteria have been proposed. These criteria, currently under review by responsible DOE personnel and NWTS program participants, are listed in Table 3.1. When DOE and programmatic concurrence is obtained, the proposed criteria will be issued as a document for public comment.

Concomitant with their applicability to all geologies, the proposed criteria are structured to address all technical and nontechnical characteristics which affect geologic waste isolation. In earlier screening studies emphasis was placed almost entirely upon demonstrating the adequacy of the hydrogeologic system to provide safe isolation. However, as technical and institutional issues have become better defined, it has become apparent that repository 1 icensing can proceed only when the total repository system (the site, the repository, and the waste package) can be shown to provide adequate and environmentally acceptable protection of public health and safety. A systematic approach to site qualification and selection based upon use of uniform predetermined generic criteria applicable to all geologic host media is an essential element in providing this demonstration.

It must be recognized that the proposed criteria are intended to constitute a comprehensive and universal set of performance requirements that must be met to qualify and select a site for a geologic repository. These criteria are therefore, of necessity, formulated in a qualitative and general manner. When appropriately quantified, however, they are applicable in the evaluation of any formation, region, area, or location in any host rock. All site recommendations in the NWTS Program will be on the basis of the proposed criteria.

Each phase of the site-qualification/selection process is conducted on the basis of (1) factors, both quantitative and qualitative in nature, that are derived from the qualification/selection criteria (see Table 3.2). and (2) specifications that prescribe numerical values for the factors (see Table 3.3). Factors and specifications are formation/medium/repositoryproject specific. For example, conceptual design engineers for a repository in a salt host rock will specify minimum thicknesses and areas for the 
TABLE 3.1. PROPOSED NWTS GENERIC SITE-QUALIFICATION CRITERIA

Criterion I. Site Geometry: The repository site shall be located in a geologic environment with geometry adequate for repository placement.

Criterion II. Tectonic Environment: The repository site shall be located such that credible tectonic events can be shown to cause no unacceptable reduction in repository performance.

Criterion III. Subsurface Hydrology and Geochemistry: The repository site shall have subsurface hydrologic and geochemical characteristics compatible with waste isolation.

Criterion IV. Surface Hydrology: The repository site shall be located so that the surficial hydrological system, both during anticipated climatic cycles and during extreme natural phenomena, will not cause unacceptable adverse impact on repository performance.

Criterion V. Geologic Characteristics: The repository site shall have geologic characteristics compatible with waste isolation.

Criterion VI. Surface Topography: The repository site and its surrounding area shall possess surface characteristics which are compatible with waste disposal.

Criterion VII. Human Intrusion: The repository site shall be located so that likelihood or consequences of past or future human intrusion will cause no unacceptable adverse impact to repository performance.

Criterion VIII. Proximity to Population Centers: The repository site shall have characteristics that tend to minimize the risk to the population from potential radiation exposure.

Criterion IX. Environment: The repository site shall be located with due consideration to potential environmental impacts, present l,and-use conflicts, and ambient environmental conditions.

Criterion $X$. Social, Political, and Economic: The repository shall be sited with due consideration to sociaT, political, and economic impacts on communities affected by the repository. 
TABLE 3.2. EXAMPLES OF FACTORS STUDIED IN MEETING NWTS GENERIC SITE-QUALIFICATION CRITERIA

\begin{tabular}{|c|c|}
\hline Criterion & Fạctor \\
\hline Site Geometry & $\begin{array}{l}\text { Depth to repository horizon } \\
\text { Thickness of host-rock unit(s) } \\
\text { Lateral extent of host-rock unit(s) }\end{array}$ \\
\hline Tectonic tnvironment & $\begin{array}{l}\text { Maximum credible earthquake } \\
\text { Recent and Quaternary faulting } \\
\text { Recent and Quaternary igenous activity } \\
\text { Long-term, continuing uplift or subsidence }\end{array}$ \\
\hline $\begin{array}{l}\text { Subsurface Hydrology } \\
\text { and Geochemistry }\end{array}$ & $\begin{array}{l}\text { Potential for nuclide migration } \\
\text { Impacts to repositnry construction } \\
\text { Subsurface rock dissolution }\end{array}$ \\
\hline Surface Hydrology & Possible impact of surface water bodies \\
\hline Geologic Characteristics & $\begin{array}{l}\text { Stratigraphic setting } \\
\text { Compatibility of host-rock with waste emplacement } \\
\text { Compatibility of host-rock with repository } \\
\text { construction }\end{array}$ \\
\hline Surface Characteristics & Potential topographic hazards \\
\hline Human Intrusion & $\begin{array}{l}\text { Potentially exploitable resources } \\
\text { Past exploration history } \\
\text { Land ownership }\end{array}$ \\
\hline $\begin{array}{l}\text { Proximity to Population } \\
\text { Centers }\end{array}$ & $\begin{array}{l}\text { Transportation } \\
\text { Urban areas }\end{array}$ \\
\hline Environment & $\begin{array}{l}\text { Potential environmental impact } \\
\text { Potential for land-use conflicts }\end{array}$ \\
\hline $\begin{array}{l}\text { Social, Political, } \\
\text { Economic Impacts }\end{array}$ & $\begin{array}{l}\text { - Wilderness areas } \\
\text { Wild and scenic rivers } \\
\text { Wildl ife refuges } \\
\text { National parks } \\
\text { Historical sites } \\
\text { Landmarks } \\
\text { Ecology }\end{array}$ \\
\hline
\end{tabular}


TABLE 3.3. EXAMPLES OF FACTORS AND SPECIFICATIONS USED IN REGIONAL SCREENING OF BEDDED SALT

\begin{tabular}{|c|c|c|}
\hline $\begin{array}{l}\text { Screening } \\
\text { Factor }\end{array}$ & $\begin{array}{c}\text { Regional } \\
\text { Screening } \\
\text { Specification } \\
\end{array}$ & Explanation \\
\hline \multirow{3}{*}{$\begin{array}{l}\text { Depth to salt } \\
\text { (saline facies) }\end{array}$} & $1000 \mathrm{ft}$ & Minimum favorable depth \\
\hline & $3000 \mathrm{ft}$ & Maximum favorable depth \\
\hline & $4000 \mathrm{ft}$ & Maximum potentially favorable depth \\
\hline \multirow{2}{*}{$\begin{array}{l}\text { Thickness of salt } \\
\text { (saline facies) }\end{array}$} & $1000 \mathrm{ft}$ & Minimum favorable thickness \\
\hline & $500 \mathrm{ft}$ & Minimum potentially favorable thickness \\
\hline Faults & $5 \mathrm{mi}$ & $\begin{array}{l}\text { Potentially unfavorable within } 5 \text { miles } \\
\text { of any mapped fault }\end{array}$ \\
\hline Igneous features & $5 \mathrm{mi}$ & $\begin{array}{l}\text { Potentially unfavorable within } 5 \text { miles } \\
\text { of any surface igneous feature }\end{array}$ \\
\hline $\begin{array}{l}\text { Groundwater } \\
\text { discharge }\end{array}$ & $\begin{array}{l}\text { Immediate } \\
\text { vicinity of } \\
\text { discharge }\end{array}$ & Potentially unfavorable \\
\hline Flooding & $1 \mathrm{mi}$ & $\begin{array}{l}\text { Unfavorable within } 1 \text { mile from rivers, } \\
\text { lakes and reservoirs }\end{array}$ \\
\hline $\begin{array}{l}\text { Energy and mineral } \\
\text { resources: } \\
\text { Petroleum }\end{array}$ & $50,000 \mathrm{bbls} / \mathrm{mo}$ & $\begin{array}{l}\text { Minimum potentially unfavorable pro- } \\
\text { duction level }\end{array}$ \\
\hline Natural gas & $\begin{array}{l}50 \mathrm{mill} \text { ion } \\
\text { cubic } \mathrm{ft} / \mathrm{mo}\end{array}$ & $\begin{array}{l}\text { Minimum potentially unfavorable pro- } \\
\text { duction level }\end{array}$ \\
\hline Uranitum ore & $\begin{array}{l}600,0001 \mathrm{~b} \\
\text { within a } 36 \\
\text { square mile } \\
\text { area }\end{array}$ & $\begin{array}{l}\text { Minimum potentially unfavorable pro- } \\
\text { duction level }\end{array}$ \\
\hline Potash & 50,000 tons/yr & $\begin{array}{l}\text { Minimum potentially unfavorable pro- } \\
\text { duction level }\end{array}$ \\
\hline \multirow[t]{2}{*}{ Urban places } & 500 population & Minimum population screened \\
\hline & $5 \mathrm{mi}$ & $\begin{array}{l}\text { Potentially unfavorable within } 5 \text { miles } \\
\text { of population center }\end{array}$ \\
\hline Wilderness areas & $\begin{array}{l}\text { Boundaries of } \\
\text { Federally des- } \\
\text { ignated areas }\end{array}$ & Unfavorable within boundaries \\
\hline
\end{tabular}


TABLE 3.3. (Continued)

\begin{tabular}{lll}
\hline $\begin{array}{c}\text { Screening } \\
\text { Factor }\end{array}$ & $\begin{array}{c}\text { Reginnal } \\
\text { Screening } \\
\text { Specification }\end{array}$ & \multicolumn{1}{c}{ Explanation } \\
\hline $\begin{array}{l}\text { Federal and } \\
\text { State lands }\end{array}$ & $\begin{array}{l}\text { National mon- } \\
\text { uments } \\
\text { National rec- } \\
\text { reation areas } \\
\text { State parks }\end{array}$ & Unfavorable within boundaries \\
& Unfavorable within boundaries \\
\hline
\end{tabular}


formation in which the repository is to be constructed. Owing to the characteristics peculiar to the respective formations, the thickness requirement becomes a significant parameter in the screening of bedded salt, while the area requirement is of great importance in the qualification of salt domes. Other specifications may involve both geological and engineering considerations. As an example, the minimum depth to the repository horizon is established by consideration of possible future surface denudation mechanisms such as glaciation or erosion. The maximum depth acceptable, on the other hand, will be based partly upon the ability of the host rock to resist overburden pressure, an important consideration in salt formations, as well as economic considerations. Similarly, environmental factors and specifications defined for a particular screening phase will reflect considerations of extant and potential characteristics, e.g., population, economic develoment, proximity to waste sources, specific to the formation under evaluation.

As already noted, the proposed NWTS criteria are directed toward the qualification and selection of sites that, considered in the context of the performance of the total repository system, will provide safe, environmentally acceptable waste isolation. Accordingly, not every single factor or specification derived from the evaluational criteria, however carefully defined, can be considered to be invariably absolute in the screening process, particularly in the earlier phases. Some factors and specifications, technical and nontechnical alike, may be unnecessarily restrictive as originally defined. In order to expedite the identification of the most favorable sites in the formation of interest, screening factors and specifications are intentionally made conservative. It is therefore. unlikely that a given region, area, or location will be found that exactly meets every specification formulated at the initiation of the particular screening phase. The decision to proceed to the next phase of the investigation is made on the basis of a thorough analysis of all of the data obtained to that point. The importance of any deviations of the findings from the prescribed specifications is assessed in the light of their probable impact on the performance of the total repository system. The validity of the specifications is also reassessed on the basis of the most recent information 
generated in the concurrent technology development studies. If it is clear that the findings of the screening phase, when they are considered within the repository-system context, indicate that the NWTS sitequalification/selection (performance) criteria are unlikely to be met, the investigation is terminated.

It is important to note that the results obtained in each phase of the screening process, as well as the conclusions developed from their analysis, are being exhaustively documented. For this reason the findings from current and earlier host-rock-specific investigations can be readily evaluated on the basis of the proposed NWTS generic site-qualification/selection criteria or on the basis of EPA/NRC criteria, when they become available.

\subsection{Methodology Employed in NWTS Geologic Explorations}

\subsubsection{General Approach}

The NWTS site-qualification/selection process involves a formalized, highly structured, and unavoidably complex sequence of literature evaluations, field explorations, and technical studies directed toward efficiently finding and credibly demonstrating the suitability of potential repository sites in geologic formations or media of interest. As already noted, the process is carried out in four phases (Figure 3-1) of sequentially more detailed technical and nontechnical evaluations. Each phase includes planning, evaluation/analysis, and documentation steps.

Planning involves, among other things, development of phase-specific evaluational factors and specifications appropriate to the hydrogeology, host rock, and environment to be studied, definition, scheduling, and budgeting of field and supporting operations required to obtain the information needed to exercise the factors and specifications, obtaining concurrence of concerned State and local authorities in the conduct of the work, preparation and submission of required environmental impact assessments for drilling operations, and selection and procurement of appropriately qualified contractors. In the planning step full cognizance is taken of the results 
The System Identification Phase - To study geologic systems and appropriate formation and rock types

The Regional Survey Phase To complete literature and field studies and evaluate and select areas for further study

The Area Study Phase - To complete reconnaissance and field work leading to the selection of locations for repositories

The Location Study Phase To complete environmental and geologic programs leading to selection of candidate repository sites

Recommendations Leading to Site Selection

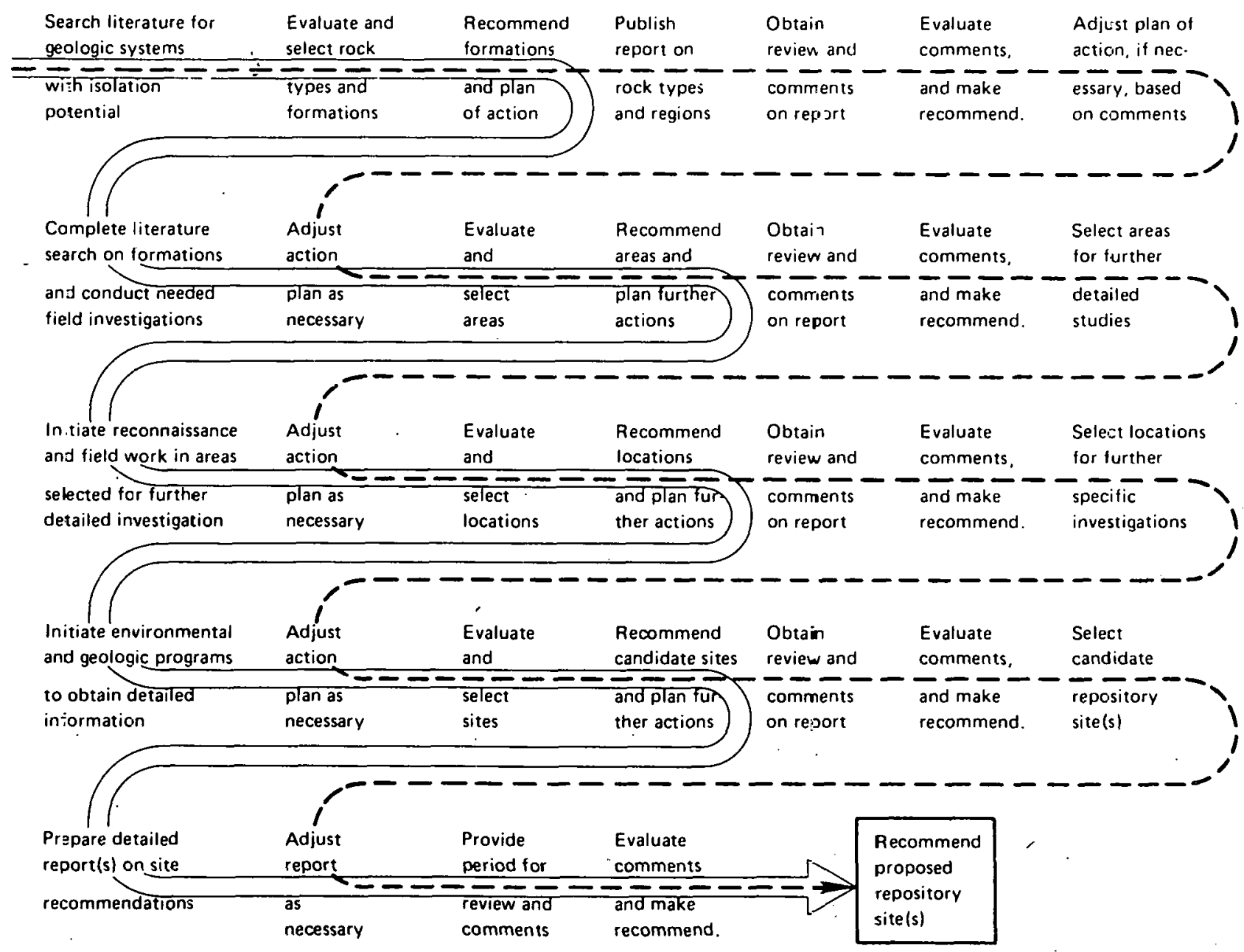


obtained in the preceding phase, as well as of the comments of independent reviewers regarding these results.

The evaluation/analys is step in each phase involves the management and coordination of the $p 1$ anned work, followed by compilation and analys is of the results obtained. As suggested by the field activity matrix presented in Table 3.4, which was prepared for an area study (the third phase of the qualification/selection process) of a bedded salt formation, every applicable exploratory and evaluational technique available to the contemporary geoscientist is marshalled in the data-gathering process. The highly conservative approach employed is readily apparent from the variety and redundancy of the techniques typically applied in developing quantitative data pertinent to each factor of concern. No opportunity to gain relevant information is allowed to remain unexploited.

Interpretation and analys is of the data are performed by specialists in the specific technologies of concern (e.g., seismicity). An overall synthesis and interpretation of the findings is obtained by application of classical geological methodology. As appreciable quantities of site-specific characterization data become available from the field studies in the third and fourth phases of the screening process. performance studies are initiated. The site-specific geotechnic and hydrologic data are evaluated by the use of various generic predictive mathematical models that have been under development for a number of years. These studies include use of release and consequence analyses to predict repository performance under normal and abnormal conditions.

As pointed out earlier, the results of the screening studies conducted in the site-qualification/selection process are thoroughly documented in each phase of the procedure. Decisions to proceed to the subsequent screening phase are based upon DOE reviews of the evaluational/analytical data presented in this documentation, as well as of the comments of outside reviewers. Although documentation procedures may vary somewhat across the NWTS Program, in the final phases, they will adhere to whatever requirements are ultimately formally defined by NRC for licensing actions. In general, the following types. of documents are being prepared: 
TABLE 3.4. EXAMPLE OF GEOLOGICAL FIELD-ACTIVITY MATRIX

\begin{tabular}{|c|c|c|c|c|c|c|c|c|c|c|c|c|c|c|c|c|}
\hline \multicolumn{5}{|c|}{ (2) } & 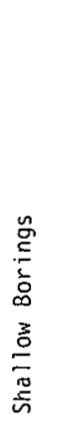 & 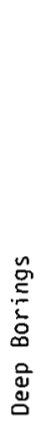 & 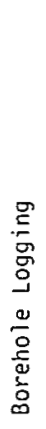 & 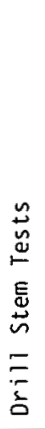 & 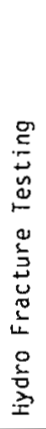 & 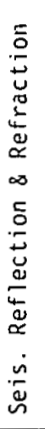 & 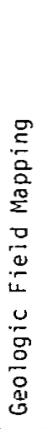 & 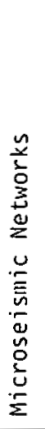 & 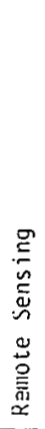 & 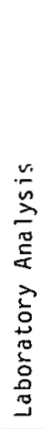 & 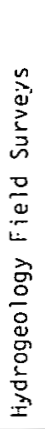 & 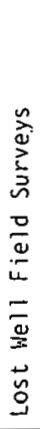 \\
\hline \multirow{42}{*}{ 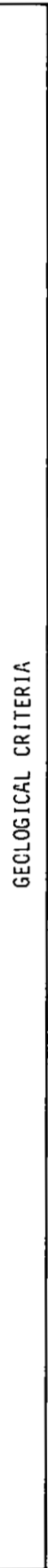 } & \multirow{27}{*}{ 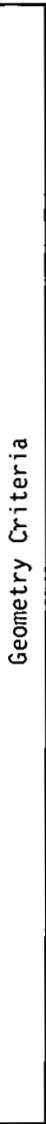 } & \multirow{9}{*}{ 吾 } & & Eolian activity & & & & & & & $x$ & & $x$ & & & \\
\hline & & & $(b)$ & Explosives & & & & & & & & & & & & \\
\hline & & & & Fluvial activity & $x$ & & & & & & $x$ & & & & & \\
\hline & & & & Glacial activity & $x$ & $x$ & & & & $x$ & $x$ & & $x$ & & & \\
\hline & & & & Hass wasting & & & & & & & $x$ & & & & & \\
\hline & & & & Heteorite inpact & & & & & & & & & & & & \\
\hline & & & & Rock type & $x$ & $x$ & $x$ & & & $x$ & $x$ & & & & & \\
\hline & & & $(\mathrm{h})$ & Topography & & & & & & & $x$ & & $x$ & & & \\
\hline & & & (i) & Wea thering & $x$ & $x$ & $x$ & & & $x$ & $x$ & & & & & \\
\hline & & \multirow{9}{*}{ 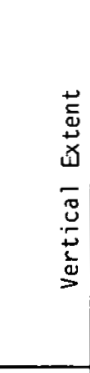 } & & Boreholes & & & & & & & $x$ & & $x$ & & & $x$ \\
\hline & & & $(\mathrm{b})$ & Dissolution & $x$ & $x$ & $x$ & $x$ & & & $x$ & & & $x$ & $x$ & \\
\hline & & & (c) & Fractures & $x$ & $x$ & $x$ & $x$ & $x$ & & $x$ & & $x$ & & & \\
\hline & & & & Homogeneity and isotropy & $x$ & $x$ & $x$ & $x$ & & & $x$ & & & $x$ & & \\
\hline & & & $(\mathrm{e})$ & Mechanical properties & $x$ & $x$ & $x$ & $x$ & $x$ & $x$ & $x$ & & & $x$ & & \\
\hline & & & & Rheological properties & & $x$ & & & $x$ & & & & & $x$ & & \\
\hline & & & & Space & & $x$ & $x$ & & & & & & & & & \\
\hline & & & & Thermal expansion & & $x$ & $x$ & & & & & & & $x$ & & \\
\hline & & & & Thermal transport behavior & & $x$ & $x$ & & & & & & & $x$ & & \\
\hline & & \multirow{9}{*}{ 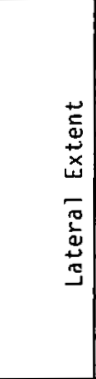 } & & Boreholes & & & & & & & $x$ & & $x$ & & & $x$ \\
\hline & & & $(\mathrm{b}$ & Dissolution & $x$ & $x$ & $x$ & $\mathrm{x}$ & & & $x$ & & & $x$ & $x$ & $x$ \\
\hline & & & (c) & Fractures & $x$ & $x$ & $x$ & $x$ & $x$ & & $x$ & & $x$ & & & \\
\hline & & & (d) & Homogene ity and 1sotropy & $x$ & $x$ & $x$ & $x$ & & & $x$ & & & $x$ & & \\
\hline & & & & Mechanical properties & $x$ & $x$ & $x$ & $x$ & $x$ & $x$ & $x$ & & & $\underline{x}$ & & \\
\hline & & & & Rheological properties & & $x$ & & & $x$ & & & & & $x$ & & \\
\hline & & & 19 & Space & & $x$ & $x$ & $x$ & & & $x$ & & & & & $x$ \\
\hline & & & & Thermal expansion & & $x$ & $x$ & & & & & & & $x$ & & \\
\hline & & & & Thermal transport behavior & & $x$ & $x$ & & & & & & & $x$ & & \\
\hline & \multirow{15}{*}{ 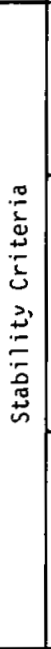 } & \multirow{4}{*}{ 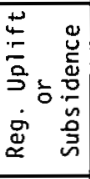 } & & Crustal loading & & $x$ & $x$ & & & $x$ & & $x$ & & & & \\
\hline & & & $(\mathrm{b}$ & Diapirism & $x$ & $x$ & $x$ & & & $x$ & $x$ & & $x$ & & & \\
\hline & & & (c) & Seismicity & & & & & & & & $x$ & & & & \\
\hline & & & $(d)$ & Tectonic history & $x$ & $x$ & $x$ & & & $x$ & $x$ & $x$ & $x$ & & & \\
\hline & & \multirow{6}{*}{$\begin{array}{l}n \\
\frac{n}{3} \\
5 \\
\leftarrow\end{array}$} & & Crustal loading & & $x$ & $x$ & & & & & $x$ & & & & \\
\hline & & & $(b$ & Diapirism & $x$ & $x$ & $x$ & & & $x$ & $x$ & & $x$ & & & \\
\hline & & & (c & Fractures & $x$ & $x$ & $x$ & $x$ & $x$ & & $x$ & $x$ & $x$ & & & \\
\hline & & & & Homogeneity and isotropy & $x$ & $x$ & $x$ & & & & $x$ & & & $x$ & & \\
\hline & & & & Seismicity & & & & & & & & $x$ & & & & \\
\hline & & & & Tectonic history & $x$ & $x$ & $x$ & & & $x$ & $x$ & $x$ & $x$ & & & \\
\hline & & \multirow{5}{*}{ 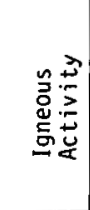 } & & Geulhermal gradient & & $x$ & $x$ & & & & & & & & & \\
\hline & & & & Magmatic activity & $x$ & $x$ & $x$ & & & $x$ & $x$ & $x$ & $x$ & & & \\
\hline & & & & Seismicity & & & & & & & & $x$ & & & & \\
\hline & & & & Tectonic history & $x$ & $x$ & $x$ & & & $x$ & $x$ & $x$ & $x$ & & & \\
\hline & & & & Volcanic activity & & $x$ & & & & & $x$ & & $x$ & & & \\
\hline
\end{tabular}


TABLE 3.4. (Continued)

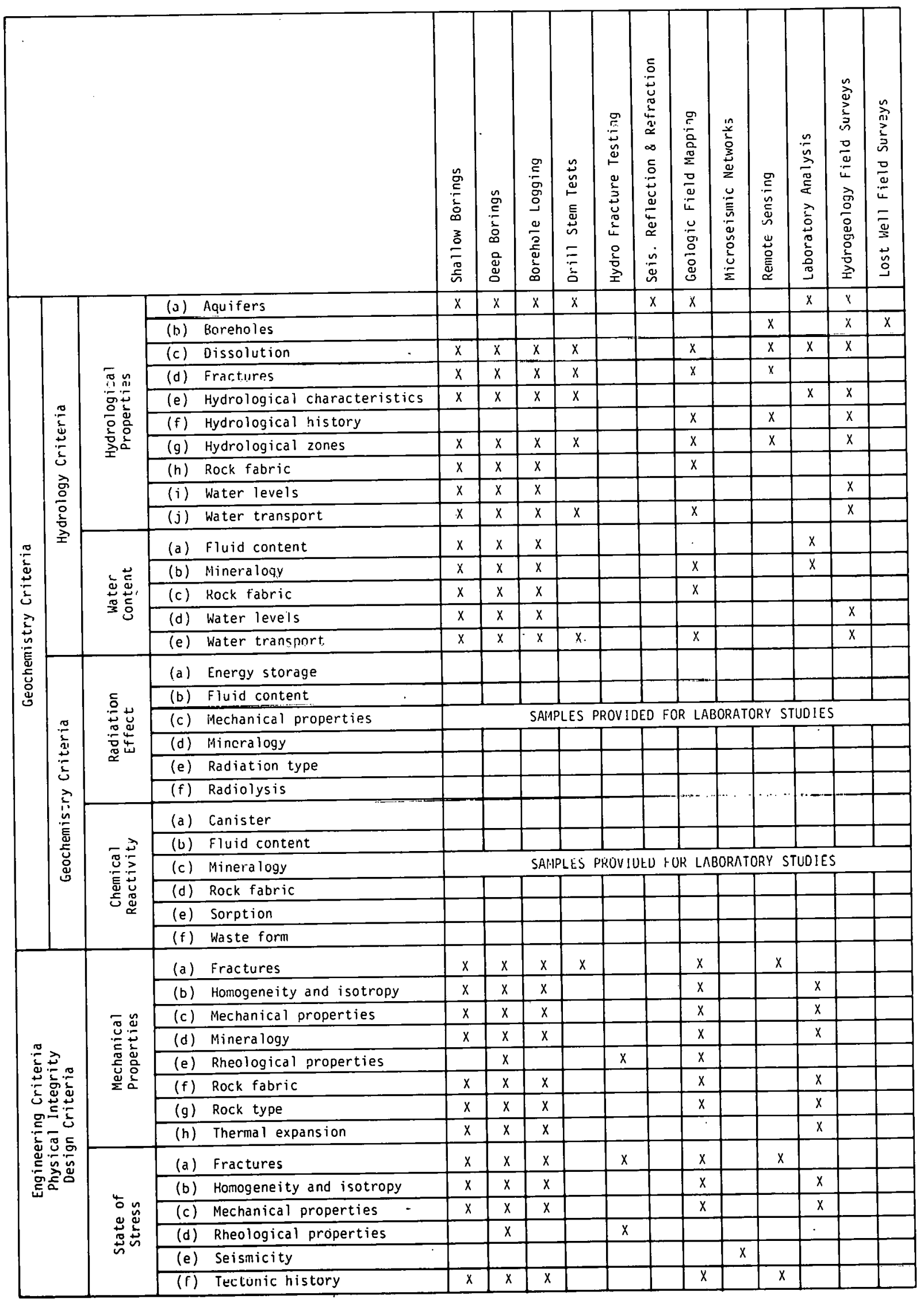


TABLE 3.4. (Continued) -

\begin{tabular}{|c|c|c|c|c|c|c|c|c|c|c|c|c|c|c|c|}
\hline & & & . & 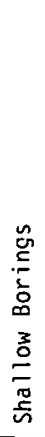 & 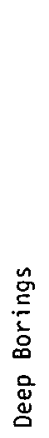 & 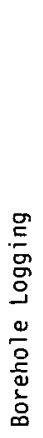 & 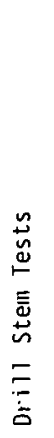 & 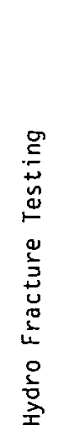 & 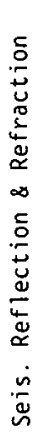 & 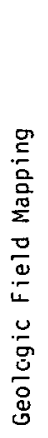 & 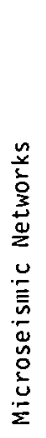 & 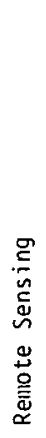 & 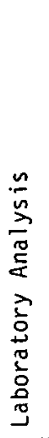 & 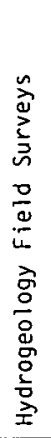 & 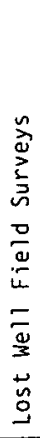 \\
\hline \multirow{11}{*}{ 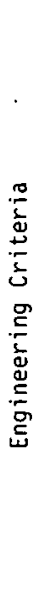 } & \multirow{2}{*}{ 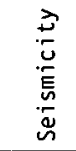 } & (a) & Seismicity & & & & & & & . & $x$ & & & & \\
\hline & & (b) & Tectonic history & $x$ & $x$ & $x$ & & & $x$ & $x$ & & $x$ & & & \\
\hline & \multirow{5}{*}{ 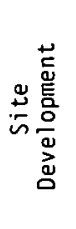 } & (a) & Facilities & & & & & & & & & & & & \\
\hline & & (b) & Land use & & & & & & & & & & & & \\
\hline & & (c) & Population & \multicolumn{12}{|c|}{ DOES NOT APPLY TO } \\
\hline & & (d) & Rock type & \multicolumn{12}{|c|}{ STUDY AREAS } \\
\hline & & (e) & Topography & & & & & & & & & & & & \\
\hline & \multirow{4}{*}{ 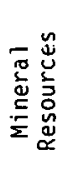 } & (a) & Resource & & $x$ & $x$ & & & & $x$ & & $x$ & & & $x$ \\
\hline & & (b) & Resource demand & & & & & & & & & & & & \\
\hline & & (c) & Resource distribution & & & & & & & $x$ & & $x$ & & & $x$ \\
\hline & & (d) & Resource grade & & & & & & & & & & & & \\
\hline \multirow{8}{*}{ 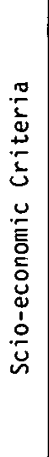 } & \multirow{7}{*}{ 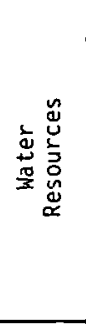 } & (a) & Aquifers & $x$ & $x$ & $x$ & $x$ & & & $x$ & & & & $x$ & \\
\hline & & (b) & Fluid content & $x$ & $x$ & $x$ & & & & & & & $x$ & & \\
\hline & & (c) & Land use & & & & & & & $x$ & & & & $x$ & \\
\hline & & (d) & Population & & & & & & & & & & & & \\
\hline & & (e) & Rock type & $x$ & $x$ & $x$ & & & & $x$ & & & & & \\
\hline & & $(f)$ & Topography & & & & & & & $x$ & & $x$ & & & \\
\hline & & (g) & Water levels & $x$ & $x$ & $x$ & & & & $x$ & & & & $x$ & \\
\hline & 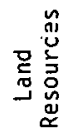 & $\begin{array}{l}\text { (a) } \\
\text { (b) }\end{array}$ & $\begin{array}{l}\text { Land use } \\
\text { Population }\end{array}$ & & . & & & & $\begin{array}{l}\text { PT } p \\
\text { HIS }\end{array}$ & $\begin{array}{l}\text { RT } 0 \\
\text { TUDY }\end{array}$ & & & & & \\
\hline
\end{tabular}


- Documents demonstrating the basis for choice of geologic media/systems for further evaluation

- Documents demonstrating the basis for choice of regions involving the media/systems for more detailed study

- Regional geologic/hydrologic/environmental characterization reports, demonstrating the basis for selection of areas in which to conduct field studies

- Plans for conducting field studies and evaluations in sperifir. areas within the regions

- Area characterization reports presenting results and analyses of area field studies and demonstrating basis for selection of potential sites for detailed evaluation

- Site characterization reports demonstrating the viability of the candidate sites.

Most of the above documents will represent consolidations, syntheses, and summaries of numerous other reports generated in the screening studies and associated scientific investigations and analytical performance evaluations.

\subsubsection{Site Screening Process}

The four phases or steps in the NWTS site-qualification/selection process are as follows:

- Identification of Formations of Interest (ONWI National Overview)

- Regional Reconnaissance Survey

- Area Studies

- Location or Detailed Confirmation Studies.

The activities undertaken in each of these four screening phases are described below. It should be noted that there are some differences among NWTS participants in the necessity to completely implement every step in this current screening procedure, owing to the availability of a substantial amount of hydrogeologic/environmental data regarding the NTS and Hanford reservations that were developed earlier in connection with other activities, as well as the less extensive geographical areas of concern in the respective 
NNWSI and BWIP efforts. In any case, all potential repository sites developed in the NWTS Program will ultimately be qualified and compared on the basis of the criteria discussed earlier. Such comparisons, as well as licensing actions, will depend on the existence of equivalent information bases.

3.2.2.1. Identification of Formations of Interest. This first phase of the site-qualification/selection process consists of a review of available technical literature and data to identify geologic formations offering potential as natural containment systems. The natural containment system sought can be based largely upon the fundamental properties of a particular host rock, such as salt or basalt, or, more desirably, upon the properties of a geologic system as a whole. In the ONWI effort, which, apart from the NTS and Hanford reservations and the WIPP site, is concerned with all of the contiguous United States, the evaluation provides a National overview of the occurrences and general properties of the particular geologic medium or system under consideration. If the results of llie review appear promising, one or more specific regions within the formation or system which appear to offer the highest potential are selected for more detailed evaluations. The U.S. Geologic Survey is supporting DOE in this effort, principally in the national overview activity and the exploration work on the Nevada Test Site.

3.2.2.2. Regional Reconnaissance Surveys. Reconnaissance surveys concentrate on the region or regions that have been identified as worthy of more detailed evaluation. Such regions may involve thousands of square miles and extend over several States. The size of the region selected is determined by the occurrence of the geologic properties of the formation or system that are thought to be favorable. The survey involves a thorough review of the available data and literature pertaining to the region or regions with special reference to those properties and characteristics which must be considered in making a reasonable evaluation. Data sources consulted include published scientific reports, geologic maps, drilling records generated in $0 i 1$, gas, and mineral exploration programs, records of earthquake occurrences and intensities, records of $0 i 1$, gas, and mineral production, and records from domestic, industrial, and municipal water-well 
drilling operations showing water depth, quality, and volume. Under unusual circumstances, when data necessary to the evaluation are insufficient or unavailable, some field work (e:g., drilling) may be conducted.

The geological properties and characteristics generally considered in regional surveys include the structure, stratigraphy, depth, thickness, and continuity of the formations; the characteristics of the groundwater systems; the physical characteristics and chemical compositions of the formations (lithology, mineralogy, petrology); the occurrence of natural resources and their current or potential exploration; the existence of folds or faults; the general surface characteristics; and the seismic stability of the region. In addition to this hydrogeologic investigation, available data regarding the environmental and socioeconomic characteristics of the region are collected and evaluated.

Depending upon the results of the study, one or more areas (about 1000 square miles) in the region may be selected for detailed study by field explorations.

3.2.2.3. Area Studies. The activities conducted in this third phase of the NWTS site-qualification/selection process are designed to develop new data, specifically of interest to the waste isolation problem, in the geographical area or areas selected for study on the basis of the results of the regional survey. Where the work in the previous phases consists of reviews and evaluations of available existing data, this phase of the screening process involves a vigorous field exploration program, as illustrated previously by Table 3.4 .

The field investigations carried out will depend to a considerable extent upon the specific study area of interest and the specific questions that need to be addressed, but will normally include core drilling, to obtain adequate definition of the total stratigraphic section; hydrologic well testing, to determine the hydrologic parameters of the rock formations; surface and aerial geophysical surveys; evaluation of aerial photography and remote sensing (Landsat satellite) data, to identify any faults or other significant structures; and field mapping of selected areas to confirm the presence of features identified from aerial photography and/or remote sensing data. 
Detailed area-specific socioeconomic and environmental data are collected and evaluated, areas are visited, and local experts are consulted to obtain up-to-date information. Environmental monitoring and sampling programs usually are not conducted in the area studies.

The product of the area studies, in addition to a thorough technical and nontechnical characterization of the area under consideration, will be, if the evaluational results have continued to prove promising, the identification for subsequent intensive investigation of still smaller areas ("locations" or potential sites) that are thought to be of appropriate size and to have characteristics and properties favorable to the construction of a waste repository.

3.2.2.4. Detailed Confirmation Studies. The detailed confirmation studies comprising the final phase of the site-qualification/selection process will be directed toward providing very detailed characterizations of specific locations of perhaps a few square miles each. These investigations will involve a very specific definition of the surface and subsurface geologic features of the area by test drilling, geophysical surveys, and field mapping. The exploration activities that will be conducted are those which will provide a thorough understanding of the geological and hydrological character of a chosen site. A similar understanding of site-specific environmental and socioeconomic characteristics will be developed. Every effort will be made to generate the data required to reasonably evaluate (by analytical modeling) and credibly demonstrate the potential risks associated with the construction, operation, and sealing of a repository at such a site. These detailed field studies will be terminated at any step in the process when the findings indicate that conditions adverse to the performance of the repository system exist at the location under investigation.

A thorough characterization of the stratigraphy will be accomplished through a combination of geologic field mapping, laboratory evaluation of cores, studies of geophysical logs obtained during drilling, geophysical surveys, and conceptual modeling. Field mapping of surface and near-surface lithologic units will be performed over and immediately surrounding the 
proposed emplacement site, if outcrops permit. Chemical and isotopic-dating analyses of selected field and core samples may be performed in some instances. Surface geophysical surveys will include use of high-resolution seismic-reflection and electrical-resistivity techniques. All information so obtained will be integrated to produce a conceptual and three-dimensional matrix model of the stratigraphy in the repository area. This model will serve as a reference for the assignment of physical parameters to groundwater-transport, thermal-conduction, mechanical-strain, and chemical effects.

The structural geology of the area will be determined by a combination of geologic field mapping, drill-core and drill-log study, and geophysical surveys, as well as by conceptual modeling of tectonic evolution. Features mapped will include the location, attitude, and displacement of observable faults and fold axes; frequency and attitude of joints, fractures, and foliations; lineaments; and distribution and attitudes of all lithologic units. Geophysical surveys will be utilized to determine groundwater salinity, lateral variations in conductivity, and vertical conductive or resistive zones. The existing state of stress will be determined by hydrofracturing.

Groundwater hydrology will be characterizcd by a combination of drill-hole hydraulic testing and conceptual and matrix modeling of the three-dimensional groundwater flow system. Isotopic dating of groundwater may be employed also in some instances. All discharge areas down-gradient from the proposed site will be determined. Recharge potential will also be determined. Drilled core samples will be tested for matrix porosity and permeability.

Physical and chemical properties of the proposed host medium, as well as the immediately adjacent media, will be determined by laboratory testing. The properties that will be determined will include thermal conductivity, diffusivity, and expansion, Young's modulus, Poisson's ratio, critical strength, bulk modulus, and sorption coefficients, as well as mineralogic and chemical composition.

The surface hydrology in the immediate proximity of a proposed site, as well as down-stream, will be characterized in detail. This analysis will 
include the occurrence, distribution, and characteristics of all streams, lakes, ponds, swamps, and wetlands. Hydraulic properties of streams will be determined at gaging stations, and chemical analyses will be performed on water samples. Seasonal variations and historical extremes for all of the relevant parameters will be determined.

The potential for the occurrence of economic amounts of natural resources (mineral/energy) will be determined by field mapping, drill-core and geophysical-log interpretation, and geophysical surveys, as well as study of documentation of past mineral and/or energy resource production from historical records. If there are indications of such resources, additional drilling will be conducted to precisely delineate the boundaries of any such resources.

A complete environmental monitoring and sampling program will be conducted in this final screening phase, which may require a year or more to complete. The objective will be to develop site-specific information in the depth required to support subsequent preparation of an environmental impact statement and a safety analysis report, should the site ultimately be selected by DOE for licensing. A site qualification report will be prepared to document the basis for site selection by the NWTS project concerned. ONWI will recommend to DOE those NWTS-qualified sites which appear, on the bas is of the data presented in the site qualification reports, beșt suited for selection by DOE for presentation to NRC in a licensing action.

\subsection{Current and Planned Exploration Efforts}

The current status of the NWTS repository site screening efforts varies considerably, depending upon the particular geologic system/host rock under investigation (Table 3.5). Of the two exploration programs on DOE reservations, NNWSI and BWIP, the latter is the more advanced. The scheduled basalt site selection date is September, 1981. In the National (ONWI) program, exploration of dome salt formations is the most advanced of the efforts underway. Selection of a site in this geology is currently scheduled for March, 1981. 
TABLE 3.5. STATUS OF NWTS GEOLOGIC EXPLORATION EFFORTS

\begin{tabular}{|c|c|c|c|c|c|c|}
\hline \multirow[b]{2}{*}{$\begin{array}{l}\text { Host } \\
\text { Medium }\end{array}$} & & \multirow{2}{*}{$\begin{array}{l}\text { Scheduled } \\
\text { Site } \\
\text { Selection } \\
\text { Date } \\
\end{array}$} & \multicolumn{4}{|c|}{ Progress in Exploration Program } \\
\hline & & & $\begin{array}{l}\text { National } \\
\text { Overview }\end{array}$ & $\begin{array}{c}\text { Regional } \\
\text { Survey }\end{array}$ & $\begin{array}{c}\text { Area } \\
\text { Studies } \\
\end{array}$ & Characterization \\
\hline Salt & $\begin{array}{l}\text { Salina basin } \\
\text { Paradox basin } \\
\text { Permian basin } \\
\text { Gulf Coast region }\end{array}$ & $\begin{array}{l}\text { None } \\
3 / 82 \\
9 / 83 \\
3 / 81\end{array}$ & $\begin{array}{l}\text { Complete } \\
\text { Complete } \\
\text { Complete } \\
\text { Complete }\end{array}$ & $\begin{array}{l}\text { Complete } \\
\text { Complete } \\
\text { In progress } \\
\text { Complete }\end{array}$ & $\begin{array}{l}\text { In progress } \\
\text { In progress }\end{array}$ & \\
\hline Nonsalt & $\begin{array}{l}\text { Systems overview } \\
\text { Crystalline rocks } \\
\text { Argillaceous rocks } \\
\text { NTS } \\
\text { Hanford }\end{array}$ & $\begin{array}{l}\text { None } \\
\text { None } \\
\text { None } \\
6 / 84 \\
9 / 81\end{array}$ & $\begin{array}{c}\text { In progress } \\
\text { In progress } \\
N A \\
\quad N A\end{array}$ & $\begin{array}{c}\text { FY } 1980 \\
\text { NA } \\
\text { Complete }\end{array}$ & $\begin{array}{l}\text { In progress } \\
\text { In progress }\end{array}$ & \\
\hline
\end{tabular}


A decision by DOE to proceed with a licensing action for one of the selected BWIP or ONWI sites would be consistent with the Strategy II repository development procedure specified in the IRG recommendations. Such a decision, of course, would be contingent on the prior endorsement of Strategy II by the President and the Congress.

The specific explorations underway or planned in the geologies of interest to the three geological repository efforts being undertaken in the NWTS Program are descibed below in accordance with the assigned NWTS programatic responsibility.

\subsubsection{Basalt Waste Project (BWIP)}

Two reservations under the control of the Department of Energy (DOE) are being investigated to determine if they are potentially suitable for a radioactive waste repository. One is the Hanford Site near Richland, Washington. During 1977 the Basalt Waste Isolation Project (BWIP)(4-7) was created to determine specifically if a site for a repository could be found within the boundaries of the Hanford Site. In addition, a major effort within the BWIP is the development of the engineering capability to design and build a repository in basaltic rock.

The Hanford Site is located in the approximate center of large formations of flood basalts known as the Columbia Plateau that covers a large portion of Washington, Oregon, and Idaho (see Figure 3-2). The investigation of the geologic and hydrologic environment has covered the gerieral region of the Columbia Plateau with specific emphasis on the Pasco Basin. The Hanford Site covers approximately 40 percent of this Basin and an understanding of its geologic and hydrologic environment is critical to making a judgment concerning the suitability of the Hanford Site. During the first two and a half years the geologic investigations have included regional reconnaissance studies conducted in the 200,000 square kilometer area of the Columbia River Basalt Group. These studies have emphasized the evaluation of the stratigraphy, structure and tectonic setting. Studies of the Pasco Basin include detailed surface geologic mapping, borehole characterization, geophysical survey, remote sensing and seismic monitoring. The conclusions 


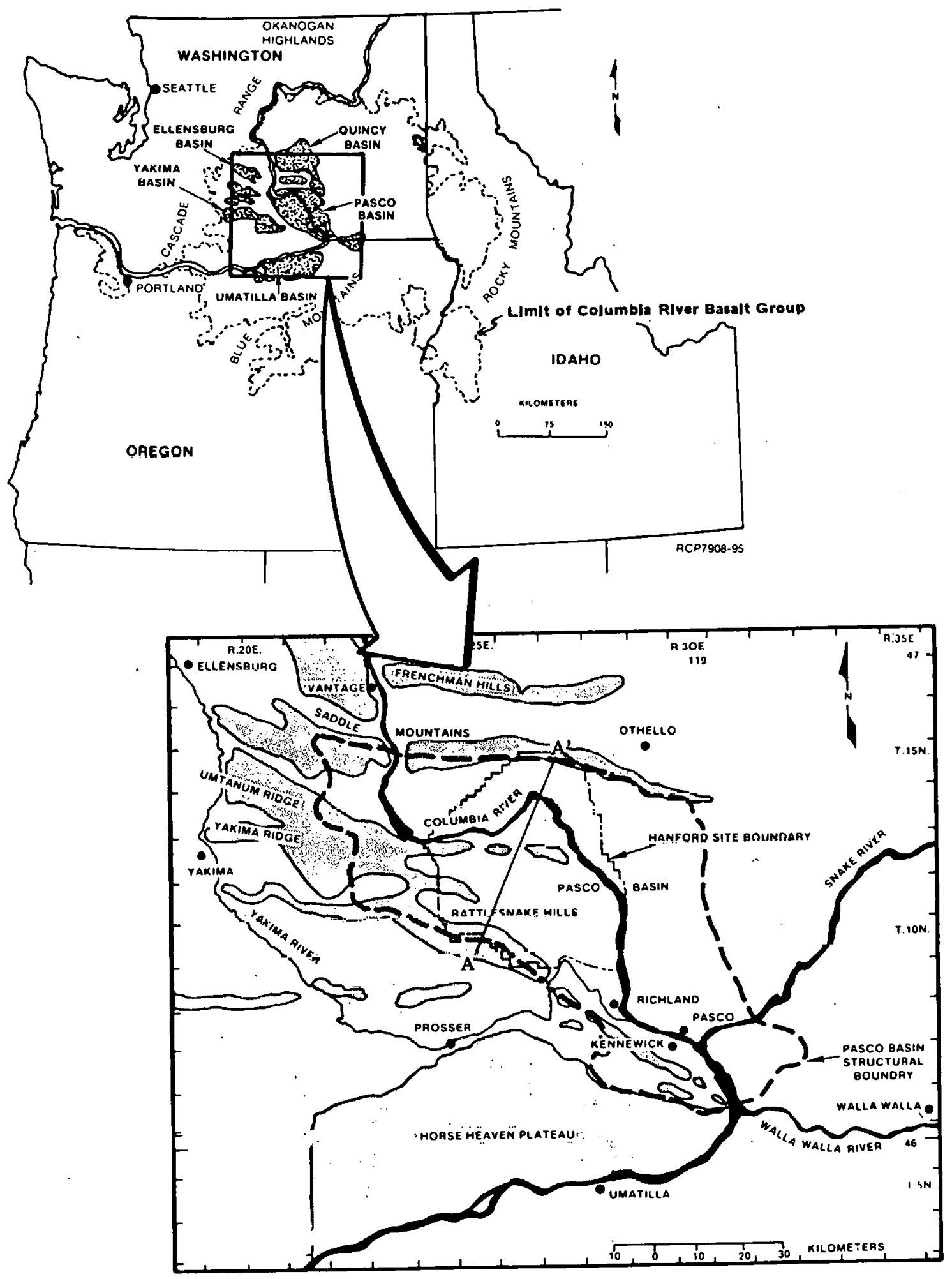

FIGURE 3-2. LOCATION MAP: OUTCROP EXTENT OF COLUMBIA RIVER BASALT GROUP, PASCO BASIN, AND HANFORD SITE 
reached, based on these studies, are that (1) the Pasco Basin is underlain by the thickest known Columbia River Basalt flows and (2) there are a few 1 aterally extensive basalt flows within the Grande Ronde Basalt which are internally dense and thick within the Pasco Basin and which could provide a location for a repository.

Early efforts in the characterization of the hydrologic conditions provided a clear model of the location and flow of the shallow ground water. Questions remain to be answered about the hydrologic environment in the basalt flows close to the level on which the repository might be built. The specific level that is being considered is approximately 3500 feet below the surface in the Grande Ronde Basalt.

Site identification studies to date have not revealed any geologic or hydrologic flaws that would cause the Hanford Site to be eliminated from further consideration. Nine possible site locations within the Hanford Site have been considered of which three appear to have a high potential for being acceptable. Further detailed studies of the three sites will be necessary in FY 1980 to evaluate them and recommend one as most favorable for a repository by the end of the fiscal year.

\subsubsection{Nevada Nuclear Waste Storage Investigations (NNWSI)}

The second DOE reservation that is being investigated is the Nevada Test Site (NTS). Like BWIP, the NNWSI Project was initiated during 1977 to determine specifically if a site for a repository could be found within the boundaries of the test site. While there are similarities in objectives for NNWSI (8-9) and BWIP, there are significant differences in certain aspects of: the program. The most significant difference is that the NTS has a specific and irrevocable mission: the testing of nuclear weapons. Therefore, the search for and potential location of a repository site must be compatible with an active program of testing of nuclear weapons. An accord has been reached between the NNWSI Project and the weapons program that limits the search for a repository site to the southwest corner of the test site (see Figure 3-3).

The second significant way in which NNWSI differs from BWIP is the fact that the NTS is characterized by a complex geologic structure featuring 


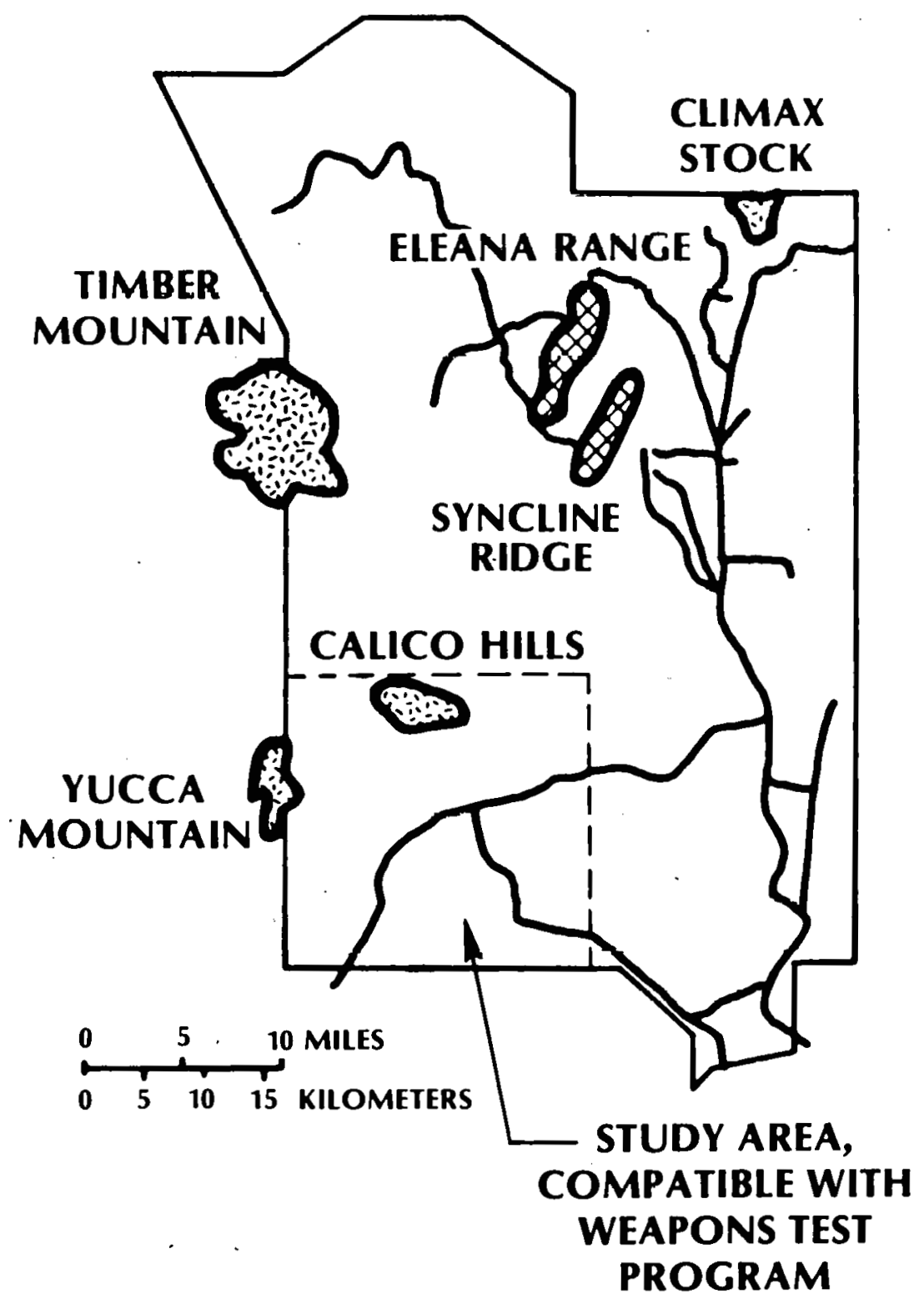

FIGURE 3-3. MAP OF NEVADA TEST SITE 
numerous geologic media (alluvium, argillite, tuff and granite). Because of this geologic diversity, the NTS has provided significant test beds to evaluate the generic features of alternative geologic media for suitability as host rock for a repository.

In the evaluation of the NTS for potential repository locations, a number of sites have been considered. Work on all but one site has been discontinued because questions concerning structural features indicated high probability for rejection. However, these sites have not been formally rejected pending review by a joint DOE-Nevada State panel that will establish the detailed criteria for site suitability in Nevada. These criteria will be consistent with generic siting criteria established by DOE for the NWTS Program.

The site that remains under active consideration is Yucca Mountain, a large tuff formation. Under the current schedule a preliminary determination concerning its suitability will be made in late 1981. However, it is estimated that it will not be possible to make an authoritative determination ahout. a tuff formation before 1984. This time is required not only to answer questions about the specific site but also questions about the engineering of a structure in tuff.

\subsubsection{National Program (ONWI)}

The present $(10)$ program continues the emphasis on exploration of salt deposits, which has been underway for quite some time. Exploration in regions underlain by salt deposits has been concentrated in four regions (Figure 3-4) previously identified as having the highest potential, geologically, for eventual successful siting of a repository. These regions are referred to as the Salina salt region, which is a combination of the Appalachian and Michigan basins, the Paradox basin, the Permian basin, and the Gulf Interior region. The first three of these regions are underlain by bedded salt. In the last region, salt domes constitute the areas of interest. These four regions were selected from the many salt-bearing sedimentary basins of the conterminous U.S., and the validity of this selection has been verified by means of a national survey. (11) The principal 


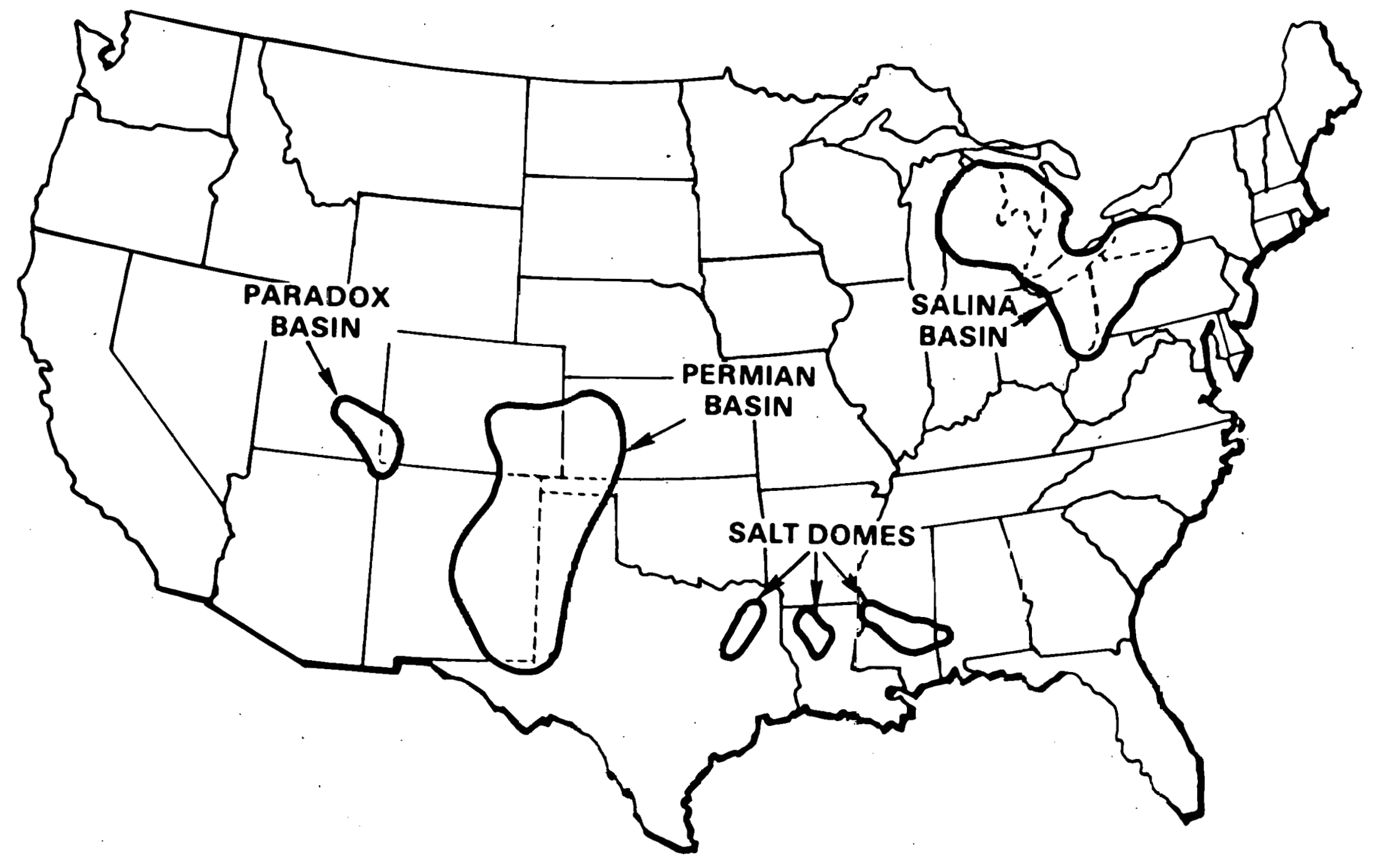

FIGURE 3-4. SALT BASINS BEING INVESTIGATED FOR TERMINAL STORAGE OF RAJIOACTIVE WASTES 
criteria used in the selection of the Salina, Permian, and Paradox basins for study were the abundance of moderately thick salt beds and occurrence of these beds at a depth appropriate for construction of a mined repository.

In the Salina salt region, the regional reconnaissance phase has been completed and areas for further evaluation have been identified in Ohio and New York (Figure 3-5).(12-16) No further work has been initiated and none is planned in the immediate future, pending resolution of State concurrence problems.

In the Paradox basin (Figure 3-6), a regional reconnaissance has been completed which identified four areas of interest.(17-19) Field work (area studies), including drilling, was initiated in one of these areas in FY 1979 and is planned for two more areas in FY 1980. A thorough review of existing data concerning the fourth area is currently underway. The field program in these areas consists of a drilling program in each area of interest, supplemented by seismic reflection surveys, limited geologic mapping, evaluation of lineaments by use of remote sensing data, and installation of a microseismic network to collect data on microearthquakes that might be related to specific structural features.

In the Permian region (Figure 3-7), a basin-wide literature review was conducted in 1976. This identified the Palo Duro and Dalhart subbasins as having the greatest potenial for siting a repository. Since this area constituted a larger area than was financially feasible to evaluate by a field program, an additional phase of study was undertaken to identify smaller areas of these subbasins that would be reasonable to initiate field programs in. This study has resulted in an extremely thorough review of existing data. $(14,20)$ Some field work was undertaken, primarily to establish a baseline on which to calibrate the existing data. It is anticipated that smaller areas having high potential, and in which detailed characterizations and evaluations can be efficiently undertaken, will be identified in the immediate future in this regional reconnaissance survey.

In the Gulf Interior region (Figure 3-8), a field evaluation program is well underway. $(19,21-27)$ A number of reviews of existing data by various organizations resulted in the identification of eight salt domes which were considered to have a high potential for siting a repository. Further 
BOUNDARIES OF SALINA SALT BASIN (APPALACHIAN AND MICHIGAN BASINS)

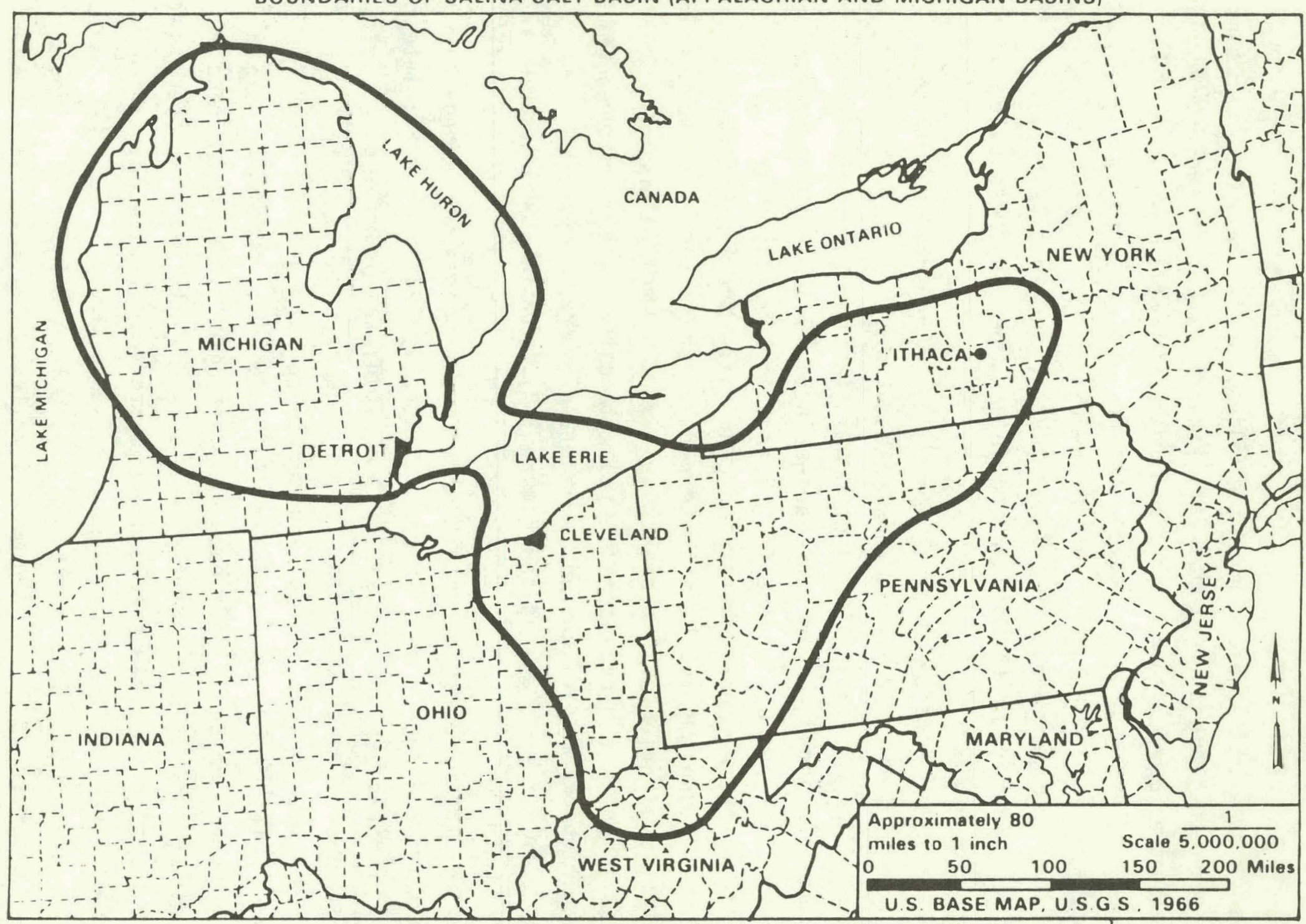




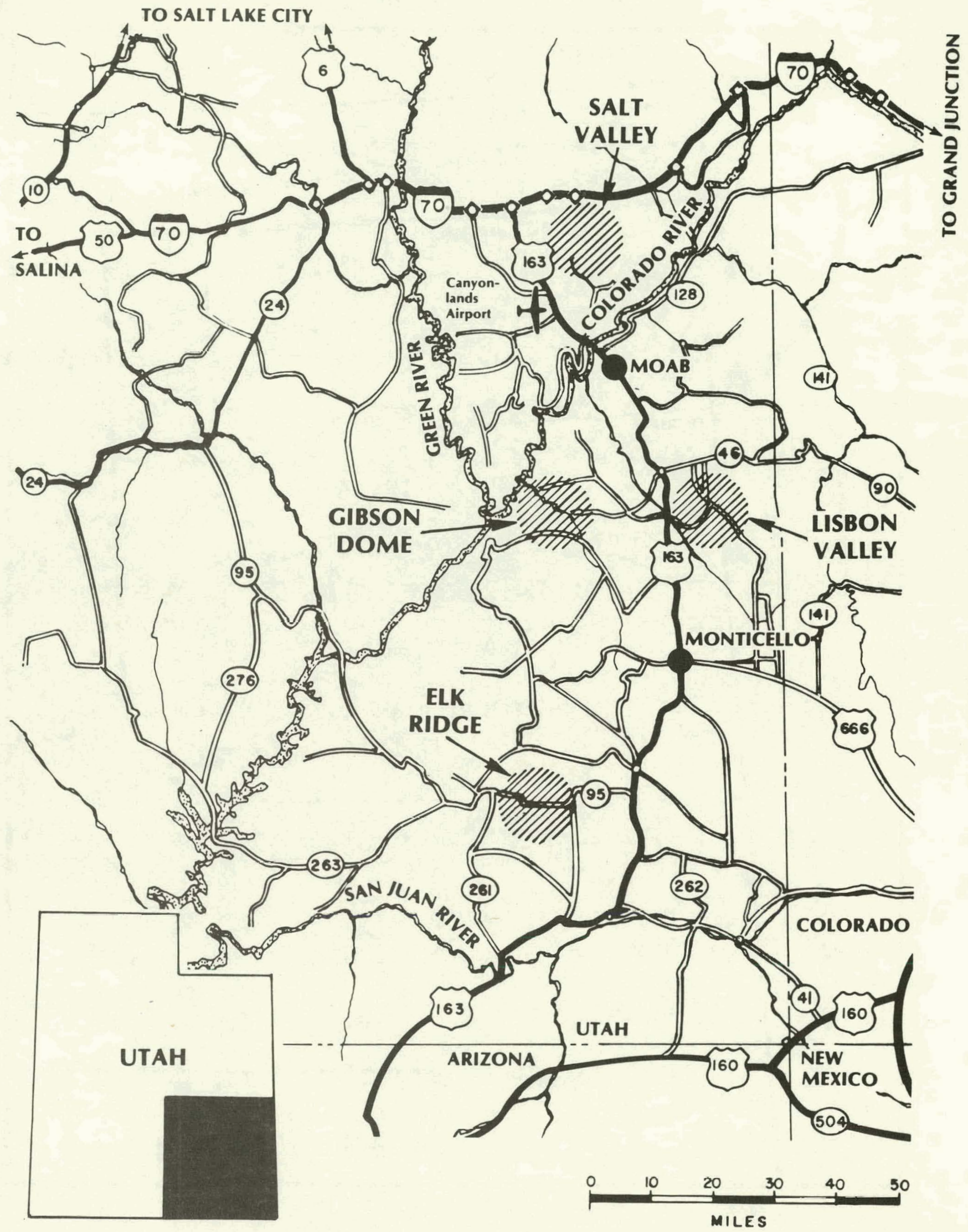

FIGURE 3-6. STUDY AREA LOCATIONS PARADOX BASIN - UTAH 


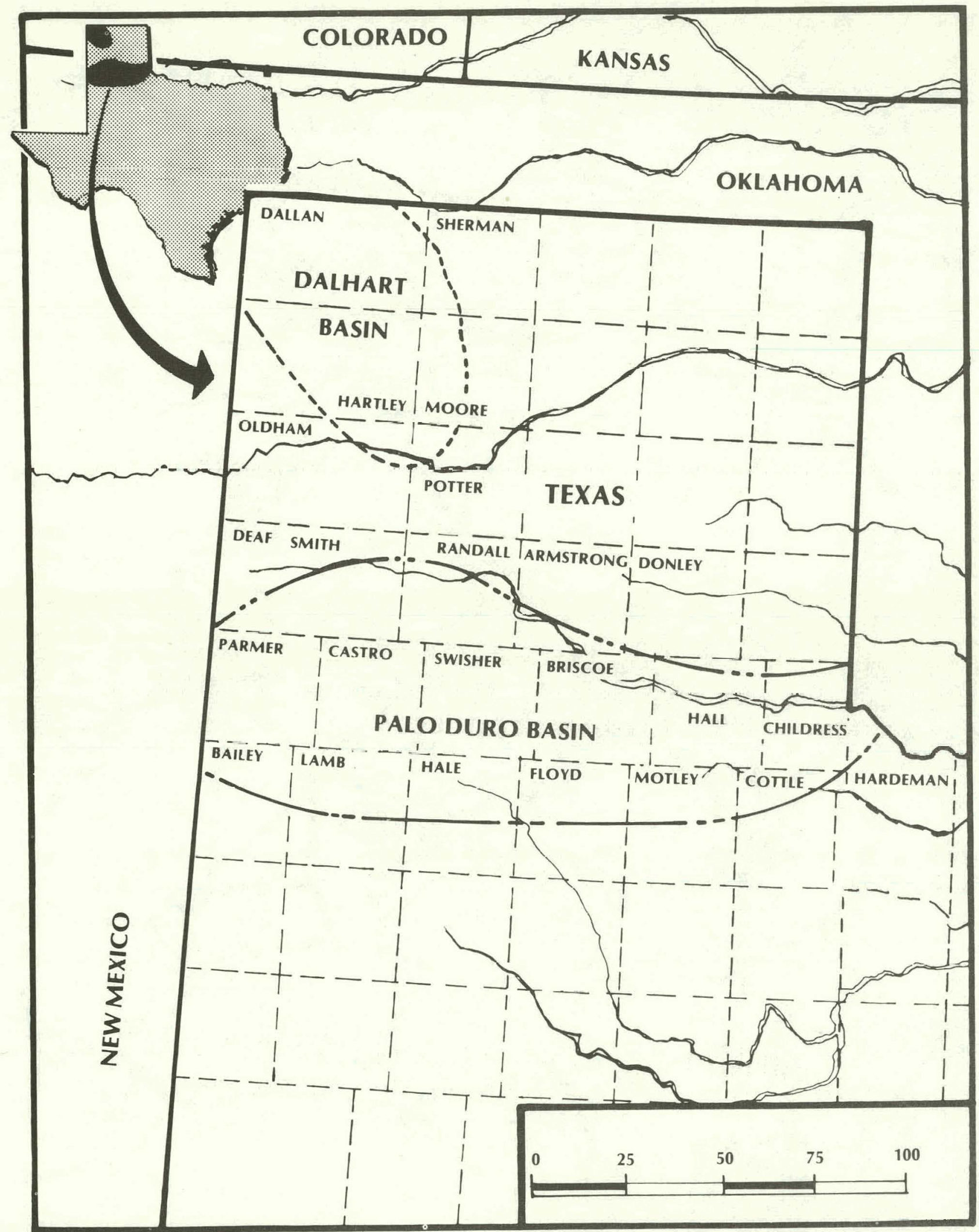

FIGURE 3-7. PERMIAN BASIN STUDY AREAS 


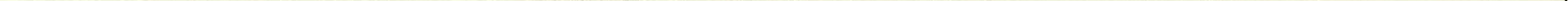


evaluation has subsequently been undertaken on most of these eight domes. Work to date in these area studies has resulted in elimination of one of the domes (Palestine Dome, Figure 3-8) owing to uncertainties regarding its hydrologic stability, largely because of previous solution-mining activities. A second dome has been tentatively identified as having conflicting land-use problems and wi11 probably be lowered in priority. Of the remaining six domes, it is anticipated that two will be identified in mid-FY 1980 as having the highest potential and will be recommended for further characterization and evaluation in detailed confirmation studies. The field program being conducted on the salt domes is directed toward an evaluation of the hydrologic and tectonic stability of the domes themselves, as well as an evaluation of the deep groundwater regime of the geologic basins in which the salt domes occur. In the exploration phase currently underway, one core hole is being drilled in each dome, and at least two hydrologic test holes are being drilled on the flanks of each dome. The drilling program is being supplemented by seismic reflection surveys to better characterize the structure of the flanking sediments, by a shallow drilling program over the dome to evaluate any possible warping of overlying sediments, by gravity surveys to more precisely delineate the sizc and shape of the domes, and by an evaluation of remote sensing data to identify any lineaments that may occur in the vicinity of the domes. In some instances, repeated precise leveling has been done over the domes, and tiltmeters have been irstalled in an effort to identify any possible current uplift.

The National program on nonsalt rocks (28-30) is underway but is wel1 behind the effort in regions underlain by salt and at the Federal reservations. The approach being utilized in the nonsalt exploration program is that of a systems study. The major portion of the systems study will be initiated and, hopefully, completed in FY 1980. However, two components of that study, specifically, National overviews of crystalline (Figure 3-9) and argillaceous (Figure 3-10) rocks, were initiated in FY 1979.

The ONWI National systems overview effort will not be specific to any particular rock type and will concentrate on geologic characteristics that are related to the total geologic system rather than on a specific host rock. Such characteristics will include groundwater retention time, 


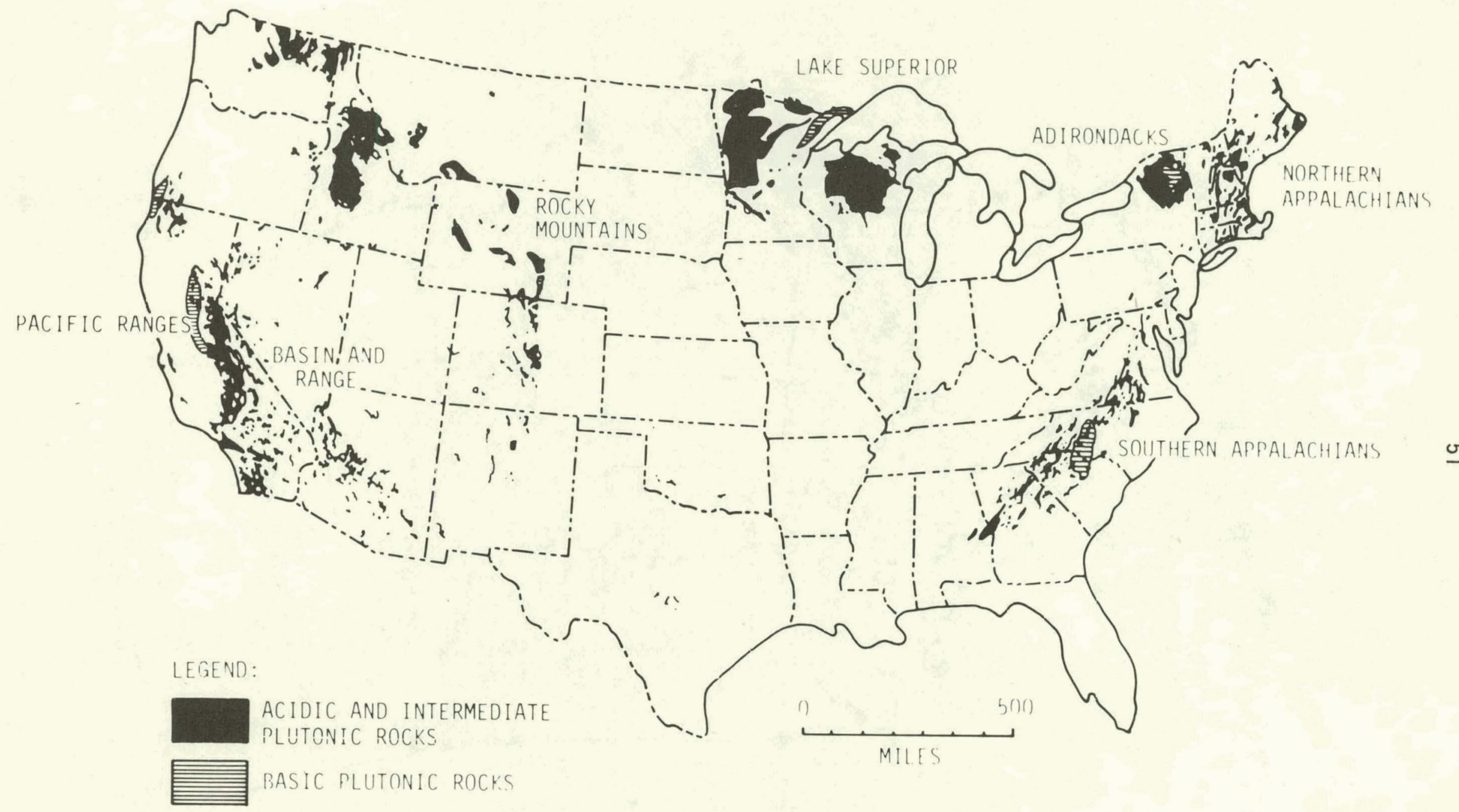

FIGURE 3-9. LOCATION OF MAJOR REGIONS OF CRYSTALLINE ROCKS IN THE UNITED STATES 


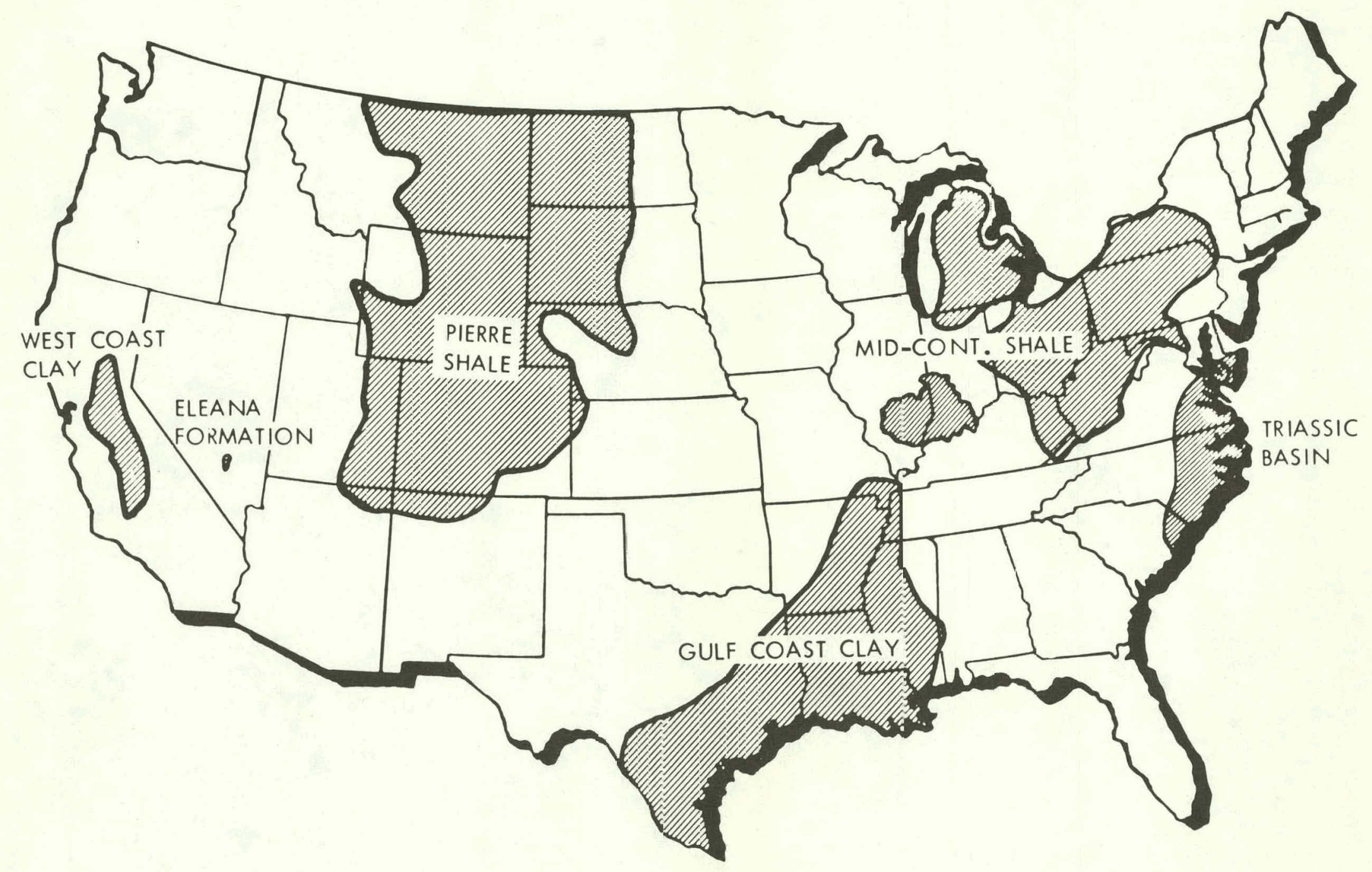

FIGURE 3-10. ARGILLACEOUS FORMATIONS IN UNITED STATES 
groundwater flow paths, and groundwater discharge patterns. Of the two components of this systems overview that were initiated in FY 1979, the crystalline rock effort is essentially completed and has identified several regions that are expected to be recommended for further evaluation. The concurrent effort underway on argillaceous rocks is expected to be completed with similar results in FY 1980.

\subsection{Proposed FY 1981 Budget for NWTS Site Screening Nctivitics}

The proposed FY 1981 budget for the NWTS geologic exploration program is presented in Table 3.6. The NWTS Program will seek to qualify potentially suitable sites on an expedited basis. In the characterization of potential sites, priority will be given to investigating all potential shortcomings and possible pathways which could lead to an inability to provide the required isolation. The FY 1981 site screening activities planned in the BWIP, NNWSI, and ONWI programs are summarized below.

\subsubsection{BWIP}

In FY 1981 the single site on the Hanford Reservation identified in FY 1980 will be further probed and evaluated, and in March of 1981 the contractor will make a formal recommendation to DOE on the site suitability for a waste repository. In this fiscal year the evaluation of the tectonic stability, economic geology and surfical processes will be completed. Hydrologic studies will provide information on deep ground water sources, discharge points, travel times, and interconnection of aquifiers.

Media studies will be conducted which will include the study of waste-rock interactions from a chemical standpoint and the analys is of the effect of heat on the basalts. The former are being studied through laboratory programs, while the latter are being studied at a Near-Surface Test Facility (NSTF): 
TABLE 3.6 PROPOSED FY 1981 BUDGET (BA, MILLIONS)

FOR NWTS SITE SCREENING ACTIVITIES

\begin{tabular}{|c|c|c|c|c|c|}
\hline Project & $\begin{array}{l}\text { Hanford } \\
\text { Basalt }\end{array}$ & $\begin{array}{l}\text { Nevada } \\
\text { Test } \\
\text { Site }(c)\end{array}$ & Salt & $\begin{array}{c}\text { Argillaceous, } \\
\text { Crystall ine and } \\
\text { Metamorphic Rocks }\end{array}$ & Total \\
\hline Project & BWIP & NNWSI & ONWI & ONWI & \\
\hline $\begin{array}{l}\text { Media Studies } \\
\text { In Situ Tests } \\
\text { Other }\end{array}$ & $\begin{array}{r}\$ 13.7^{(a)} \\
7.5^{(b)}\end{array}$ & $\begin{array}{r}\$ 2.5 \\
2.5\end{array}$ & $\begin{array}{r}\$ 11.8^{(\mathrm{d})} \\
8.5^{(\mathrm{e})}\end{array}$ & $\begin{array}{r}\quad \$ 2.9^{(h)} \\
2.5^{(i)}\end{array}$ & $\begin{array}{c}\$ 30.9 \\
21\end{array}$ \\
\hline Regional Studies & & & & 15.1 & 15.1 \\
\hline Area Studies & & & $3.2^{(f)}$ & & 3.2 \\
\hline \multirow[t]{2}{*}{ Site Studies } & 16.3 & 11.8 & $20.7^{(g)}$ & & 48.8 \\
\hline & $\$ 37.5$ & $\$ 16.8$ & $\$ 44.2$ & $\$ 20.5$ & 119.0 \\
\hline
\end{tabular}

(a) Near Surface Test Facility.

(b) Engineered Barrier Studies.

(c) NTS studies include granite, tuff and argillite.

(d) Salt Test Facility construction funds included.

(e) Approximate, includes rock characterization, waste/rock interaction, and repository sealing studies.

(f) Area studies in the Permian Basin.

(g) Site studies in Gulf Interior $(\$ 9.1 \mathrm{M})$ and the Paradox Basin $(\$ 11.6 \mathrm{M})$.

(h) Non-Salt Test Facility.

(i) Approximate, includes rock characterization and waste/rock interaction studies. 


\subsubsection{NNWSI}

Activities in FY 1981 will focus primarily on the characterization of the Yucca Mountain site. Media studies will be conducted on granite and tuff. Efforts will focus on the chemical, physical and mechanical properties of tuff to determine if it is a suitable medium for a repository.

\subsubsection{ONWI}

3.4.3.1. Salt. A primary site recommendation by the contractor is planned for a Gulf Coast salt dome in March of 1981. In addition, siting and area studies will proceed in the Paradox and Permian basins, respectively. In addition, the Salt Test Facility will be operated to gather data on the salt medium.

\subsubsection{Argillaceous and Crystalline Media. A field test} facility is planned for FY 1981 to gather data on either argillaceous or crystalline media. Regional studies will proceed in FY 1981 to identify candidate areas.

\subsection{Relation of the Site Screening Program to the IRG Recommendations}

As the lead agency in the National waste management effort, the DOE has made extensive plans for the formal imlementation of the IRG recommendations. Some of the recommendations that do not involve a Presidential policy decision have been implemented, while others speak to policies that have been in force in the program from its initiation (e.g., technical conservatism, interagency cooperation). Specific DOE responses to those IRG recommendations which relate to 'the site-qualification/selection process are described briefly below. 


\subsubsection{A Systems Approach Shou 1d Be Stressed}

This recommendation has been implemented in the NWTS Program. As already noted, the repository system is viewed as consisting of three interacting components: the waste package, including associated overpacks, the repository, and the site. The site component includes the hydrogeological system and the host medium involved. The system is conceived as a series of natural and engineered barriers between the waste and the biosphere. Systems studies are directed toward integrating the components in such a manner as to achieve optimum waste isolation performance, defining interfaces (i.e., bounding the system and its functional components) and impacts, defining alternatives, and credibly demonstrating the performance of the system by analytical modeling.

The modeling studies, as explained earlier, are an integral function of the site-qualification/screening process. Making use of various models developed in the NWTS technology program, analytical evaluations are initiated when site-specific quantitative data become available from the hydrogeologic explorations. Generic geologic, hydrologic, and media characterization and performance data, also developed in the NWTS technology program, scrve as input to the analyses. They are directed toward assessment of both design and operational risks (near field) and long-term (far field) repository system. performance risks. Many separate studies have been undertaken in the NWTS Program to develop this modeling capability and its requisite data base.

For example, studies underway in the area of rock mechanics are directed toward elucidation of the thermomechanical impacts of the waste and include efforts such as defining the extent of fracturing of the host rock that may arise from mining, seismic events, and heat from the waste; developing models to predict the transport of water through fractured media; and conducting laboratory and field measurements of water flow through fractured rock to obtain data for comparison with analytical models.

Similarly, studies are being directed toward defining waste/media interactions. These are creating great interest since the concept. of multiple barriers is receiving more attention as a mechanism to provide 
defense in depth. Changes in chemical and physical properties to be expected under the influence of heat and radiation will be studied for the waste, the canister, the backfill material, the original geologic media, and the groundwater. The degree of brine migration in rock salt, leaching of the waste form, corrosion of the canister, and effectiveness of potential barriers will be examined in elevated-temperature/pressure tests performed both in the laboratory and in the field.

The broadest issue of all is the degree to which we are able to assess the long-term risk. Investigations addressing this problem include, as examples, studies of our ability to predict tectonic stability, future climatic conditions, and potential events and mechanisms which could lead to transport of radionuclides. Models are being developed to assess the long-term safety of repositories in salt and in hard rock. A large number of potential events that could affect repository system performance are being examined.

\subsubsection{A Number of Different Sites in Various Types of Rock Formations Should be Evaluated}

The ongoing and planned BWIP, NNWSI, and ONWI exploration programs described earlier furnish ample evidence of DOE's implementation of efforts responsive to this recommendation. Owing to the lead time involved in the qualification/selection process, selection of sites in alternative geologies (e.g., crystalline rock, argillac'eous rock) will occur several years after site selection in the more advanced exploration programs. Accordingly, DOE plans to consult with DOI to develop mechanisms to "bank" sites (to prevent their preemption for other uses) as they are qualified and selected. The availability of a number of fully qualified sites in various formations will, of course, facilitate implementation of IRG Strategy III as well as the recommendation for regional repositories, should these become National policy.

Some important aspects of the planning of DOE geological explorations that have not been discussed above, and which may promote an appreciation of both the comprehensiveness of the DOE geological screening process and its consonance with IRG recommendations, are the technology development efforts that have been undertaken in connection with the NWTS 
Program. Many of the studies underway or planned for the immediate future directly contribute to the efficiency and technical validity of the site screening process. Numerous such studies have been implemented to secure quantitative information regarding the fundamental properties and the behavior of host media/formations of potential programatic interest as well as of the characteristics of associated hydrologic systems. The information developed enhances DOE's ability to interpret the results of the hydrogeologic data obtained in the screening studies and furnishes baseline data for repository system design and site performance analyses.

The U.S. Geological Survey is playing a significant role in the development of this information base. USGS scientists are studying the geologies and hydrologies of the various salt areas as well as those at the NTS, the Hanford reservation, and elsewhere. Representatives from each DOE project and the USGS have prepared an Earth Science Technical Plan(3) that presents the R\&D tasks being performed for DOE and by the USGS. The plan comprises over 160 separate tasks, ongoing or planned, for $F Y 1979$ and beyond. The studies involve currently about 40 contractors, including national laboratories, state and federal agencies, universities, and other DOE prime contractors and subcontractors. The initial plan will be reviewed periodically to assess progress and to assure close coordination between various tasks. The tasks cover the full range from analytical studies and laboratory experiments to field testing.

The studies may be loosely grouped into two of ten overlapping areas: evaluations of geologic environments (generic, regional, and local) and site characterizations (geology, hydrology, and host media).

The first grouping addresses the generic suitability of such media as granite, argillite, tuff, or alluvium and the choice of one region, locality, or lithology over another. The wide range of media is being examined, in large part, to upgrade the state of knowledge of these media closer to that which exists for rock salt. In addition, regional studies are included to identify promising formations, some of which may have natural, multiple barriers to the escape of radioactivity.

The second grouping addresses detailed characterization of specific sites and development of methods for obtaining more precise geologic data. 
The studies here treat shape and extent of the geologic structures; discontinuities in stratigraphy, mineral distribution, and tectonic stability; hydrologic properties, including hydraulic potential, permeability, groundwater flux and its chemical content; and media properties, including the physical and chemical aspects of a candidate site.

Not all data required can be obtained from laboratory tests. Accordingly, some experiments are being conducted in a field environment. Variables such as lithostatic pressure of hydrology cannot be readily simulated in the laboratory. The common feature of these tests is the need to evaluate combined effects that are sufficiently complex that only tests in the field environment can provide confidence in the results.

The long-term performance of a repository cannot be experimentally demonstrated; thus, the models used to assess long-term safety must be verified. To satisfy these needs, various field experiments are underway or are being planned in several candidate media. In these field studies, the most important variables include temperature, rock displacement, hydrology, geochemistry, radiochemistry, and nuclide migration.

A we 11-known example of this research is the field test program being conducted at the Stripa mine in Sweden. These tests are providing field data on the effects of long-term high heat loadings on the integrity of granite in deep geologic formations. The experiments are also providing a means of evaluating techniques for characterizing the fracture hydrology of granite. The work, being carried out in conjunction with Swedish waste management scientists, is an example of the international cooperation and participation sought by $D O E$ in solution of common waste management problems.

Another DOE field test program is being planned to obtain experimental data on host geologies other than salt and granite. The in situ data base developed will be used for the validation of waste disposal modeling efforts associated with alternative geologies and for comparison with a much broader data base obtained in laboratory studies of the host media of interest. The planned program will involve the construction and operation of an Alternate Geologies Test Facility. 


\subsubsection{Planning Should Be in Full Compliance With NEPA}

A comprehensive planning effort has been mounted to assure that all field operations connected with the NWTS site-qual ification/selection process are implemented in a manner that will be in full compliance with EPA guidelines and regulations and that the documentation ultimately submitted to NRC in support of a licensing action will adequately address all considerations associated with meeting EPA criteria and standards for waste isolation. As part of this effort a formal documerit will be developed that describes how the NEPA process will be applied in the implementation of the NWTS Program. The intent will be to provide program participants and the public with a cohesive and understandable explanation of the planned DOE procedure. A similar document will present a comprehensive, detailed plan for licensing a geologic waste repository. The strategy, the procedure, and the data and information needed to obtain a license will be described. These documents are intended to promote an understanding of the motivation, structuring, and sequencing of the technical and nontechnical activities being undertaken in the complex and wide-ranging NWTS Program among participants and concerned observers al ike.

The environmental evaluations conducted in the geologic screening studies have been discussed above. Apart from the development of NEPA-consistent program-wide site-qualification criteria, the planning of these activities has included the preparation of outlines for the ER and EIS documents that will be required in any licensing action to comply with the NEPA process. These efforts were undertaken to assure that ongoing and planned field studies will provide the information base requisite to the preparation of these documents. The site-recommendation reports DUE pians to prepare in the final phase of the selection process are planned to include EIS's.

To facilitate the field testing activities $\mathrm{planned}$ in the NWTS technology development program, DOE is considering operation of a Salt Test Facility and an Alternate Geologies Test Facility. As part of the site evaluations for these installations, environmental impact assessments will be 
implemented to assure that no significant impact on the environment will result from either their construction or operation. Potential environmental effects anticipated on the surface and underground will be studied.

\subsubsection{A Social Consensus Must be Obtained; A State Planning Council Should be Formed}

The DOE nuclear waste management program in general and its most visible manisfestation, the geological explorations, have, quite predictably, stimulated misgivings and controversy among various sectors of the public, including state and local governments. The motivation, objectives, and methodology of the program as a whole, and the site screening activities in particular, are not well understood outside of the waste management community. Geologic exploration activities are sometimes interpreted as evidence of a unilateral decision on the part of the DOE to construct a repository in the area under investigation. Such misperceptions have prompted some state and local governments to restrict or deny access for exploration work.

In recognition of this problem DOE has been developing and applying procedures to promote a high level of public participation and review of all aspects of the nuclear waste management program in the belief that the more knowledgeable the public, and its governmental representatives, becomes about the effort the more likely it will be possible to obtain a reasonable consensus regarding the socially responsible and responsive manner in which it is being implemented. The DOE has initiated a comprehensive public information program designed to explain waste management activities in terms that technically unsophisticated people can understand and to provide access to technical documents issued in connection with the exploration and scientific activities. Drafts of important technical and policy documents are offered for public and technical comments. Various independent review groups have been established by ONWI, BWIP, and NNWSI to secure advice and consultation about both the content and conduct of the program. These technical review groups are listed in the Appendix along with their membership. Technical information meetings held to review progress on the three NWTS programs are completely open to the public. Individuals known to 
have an interest in waste management issues are specifically invited to attend, regardless of their viewpoints.

Detailed planning is in progress on formal implementation of procedures responsive to the IRG recommendation for establishment of a State. Planning Council to advise the President, the Congress, and the Secretary of Energy on matters related to concerns regarding the waste management program. Among the tasks that might be assigned to the State Planning Council are:

- Provide state perspectives for the development of the National Nuclear Waste Management Plan, the site characterization program and other waste activity planning and other planning documents to ensure that they adequately address the needs of the States and localities;

- Prepare an annual report to the President, the Congress and the Secretary of Energy on its activities to include its recommendations concerning the government's nuclear waste disposal programs;

- Advise on the regional distribution of site characterization activities and $\mathrm{placement}$ of facilities for the management and disposal of nuclear wastes and review and make recommendations regarding the process of selecting, characterizing and placement of facilities for the management and disposal of nuclear wastes and review and make recommendations regarding the process for selecting, characterizing and determining the suitability of potential repository sites;

- Assist DOE and the States in recommending proposed sites for licensing by NRC to assure that the needs of the States and localitics arc met;

- Assist and advise on the implementation of the consultation and concurrence concept;

- Establish under its auspices such advisory committees as are deemed necessary to assist in its deliberations, including representatives of all relevant interest groups;

- Define additional State factors in the Federal Government's waste management program, including State organizational and other institutional questions. 
Establishment of the State Planning Council will require a Presidential decision to implement the IRG recommendation, together with enabling legislation from the Congress.

An example of the kind of State/DOE cooperation that is sought in the consultation and concurrence process has been achieved in the State of Mississippi, where explorations of Gulf Interior salt domes are underway. Key elements in this cooperation are a DOE contract with the Mississippi Fuel and Energy Management Commission and the maintenance of a close working relationship with the administration of the Governor and his Select Committee on Nuclear Energy. The State Division of Radiological Health, the Mineral Resources Institute, and State Department of Natural Resources, al represented on the Governor's Select Committee, are required by a 1979 law to be notified and be permitted to participate in NWTS activities in the state.

Under a DOE grant, the Fuel and Energy Management Commission provides an independent assessment of state government and public views on one hand and, on the other, a forum for legislators, state and local officials, and citizens to air their views on DOE activities. As a practical matter, the grant also gives the commission an added funding source, while assuring it a major role in the NWTS Program in the state. 


\section{REFERENCES}

(1) "Report to the President by the Interagency Review Group on Nuclear Waste Management", TID-29442.

(2) "Draft Environmental Impact Statement, Management of Commercially Generated Radioactive Wastes", DOE/EIS-0046-D.

(3) "Earth Science Technical Plan for Mined Geologic Disposal of Radioactive Waste", TID 29018 (Draft).

(4) Rockwell-Hanford Operations, "Basalt Waste Isolation Program Plan", RHO-CD-132 REY 3 (May, 1979).

(5) Deju, R. A., "Status Report on Studies to Assess the Feasibility of Storing Nuclear Waste in Columbia Plateau Basalts", Proceedings of the National Waste Terminal Storage Program Information Meeting, ONWI-6? (October 30, 1979).

(6) "Site Identification Presentation, Basalt Waste Isolation Project", RHO-BWI-LD-22 (November, 1979).

(7) Basalt Waste Isolation Project Annual Report, Fiscal Year 1979", RHO-BWI-79-100 (November, 1979).

(8) "Nevada Nuclear Waste Storage Investigations, FY 1979 Project Plan", NV0-196-9 (Marcil, 1979).

(9) Lincoln, R. E., "The Nevada Nuclear Waste Storage Investigations", Proceedings of the National Waste Terminal Storage Information Meeting, ONWI-62 (October 30, 1979).

(10) "Technical Program P1an", ONWI-19 (February, 1979).

(11) Johnson, K. S., arid Gurzales, S. "Salt Ueposits in the United States and Regional Geologic Characteristics Important for Storage of Radioactive Waste", Y/OWI/SUB-74124-1 (March, 1979).

(12) Peck, J. H., Pierce, D. S., and Picking, L. W., "Geology and Hydrogeologic Modeling in the Saline Basin, New York and Ohio", Proceedings of the National Waste Terminal Storage Information Meeting, ONWI-62 (October 30, 1979).

(13) Norris, S.E., "Summary of Studies of Deep Formational Water Associated with the Salina Group, Ohio and New York", Proceedings of the National Waste Terminal Storage Information Meeting, ONWI-62 (October 30, 1979).

(14) DiNunno, J. J., Waite, D. A., and McIntosh, W. H., "Environmental Surveys of the Permian and Salina Basins", Proceedings of the National Waste Terminal Storage Information Meeting, ONWI-62 (October 30, 1979). 
(15) "The Silurian Salt Deposits in Eastern Lake, Northwestern Astabula, and Northeastern Geauga Counties, Ohio", USGS Open File Report 79-269 (1979).

(16) "Hydrologic Environment of the Silurian Salt Deposits in Parts of Michigan, Ohio, and New York", USGS Open File Report 78-684 (1978).

(17) Conwell, F. R., "Regional Geologic Screening Studies for Waste-Repository Siting in the Paradox Basin", Proceedings of the National Waste Terminal Storage Information Meeting, ONWI-62 (October 30, 1979).

(18) Hite, R. J., et al., "Geologic Screening in Salt Valley, Utah", Proceedings of the National Waste Terminal Storage Information Meeting, 0NWI-62 (October 30, 1979).

(19) Norman, N. A., and Glora, M. A., "Environmental Surveys of the Guif Interior Region and the Paradox Basin", Proceedings of the National Waste Terminal Storage Information Meeting, ONWI-62 (October 30, 1979).

(20) Gustavson, T. C., et al., "A Multidisciplinary Geologic Approach to Basin Evaluation for Nuclear Waste Management, Palo Duro Basin, Northwest Texas", Proceedings of the National Waste Terminal Storage Information Meeting, ONWI-62 (October 30, 1979).

(21) Durham, C. 0., Jr., "A Review of Gulf Coast Salt-Dome Evaluations", Proceedings of the National Waste Terminal Storage Information Meeting, ONWI-62 (Oc tober 30, 1979).

(22) Pau 1son, 0. L., Jr., "Cypress Creek Dome, Mississippi", Proceedings of the National Waste Terminal Storage Information Meeting, ONWI-62 (0ctober 30, 1979).

(23) Martinez, J. D., "Tectonic and Hydrologic Stability of Louisiana Salt Domes", Proceedings of the National Waste Terminal Storage Information Meeting, ONWI-62 (October 30, 1979).

(24) Kreitler, C. W., "Evaluation of East Texas Interior Salt Domes", Proceedings of the National Waste Terminal Storage Information Meeting, ONWI-62 (Oc tober 30; 1979).

(25) Hosman, R. E., "Regional Groundwater Hydrology of the Northern Lou isiana Salt Dome Basin in Relation to the Storge of Nuclear Wastes", Proceedings of the National Waste Terminal Storage Information Meeting, ONWI-62 (Oc tober 30, 1979).

(26) Spiers, C. A., "Regional Groundwater Hydrology of the Mississippi Salt-Dome Basin in Relation to the Storage of Nuclear Wastes", Proceedings of the National Waste Terminal Storage Information Meeting, ONWI -62 (October 30, 1979). 
(27) Marine, I.W., "Evaluations of Subregions in the Southwestern United States", Proceedings of the National Waste Terminal Storage Information Meeting, OWNI-62 (October 30, 1979).

(28) Murrie, G. W., and Gates, T. M., "Geologic Evaluation of Crystalline Intrusions and Selection of Candidate Areas for Detailed Investigations", Proceedings of the National Waste Terminal Storage Information Meet ing, ONWI-62 (October 30, 1979).

(29) Gonzales, S., and Johnson, K. S., "Preliminary Assessment of Argillaceous Basins in the United States". Prnceperings of the National Waste Terminal Storage Information Meeting, ONWI-62 (October 30, 1979).

(30) Brunton, G. D., "Evaluation of Argillaceous Rock for Nuclear Waste Containment", Proceedings of the National Waste Terminal Storage Information Meeting, ONWI-62 (October 30, 1979). 
APPENDIX

NUTS PEER REVIEH GROUPS 
A-1

\section{APPENDIX}

\section{NHTS PEER REVIEH GROUPS}

The peer review groups of the NWTS Program are listed below. Ten separate review groups have been convened:

- ONWI Technical Advisory Committee

- ONWI Geologic Review Group

- ONWI Earth Sciences Review Group

- ONWI Program Review Committee

- BWIP Rock Mechanics Overview Committee

- BWIP Geology Overview Committee

- BWIP Hydrology Overview Committee

- NNWSI Media Studies Technical Peer Review

- NNWSI Geology and Hydrological Studies Technical Peer Review

- NNWSI Spent Fuel Test at Climax Technical Peer Review

- NNWSI Tectonics, Seismicity and Volcanism Technical Peer Review.

The first seven groups perform continuing reviews, while the NNWSI review groups have been invited on a case by case basis. 


\section{ONHI TECHNICAL ADVISORY COMMITTEE}

\section{Name}

F. W. Albaugh, Chairman

T. W. Ambrose

R. F. Bauer

James L. Boyd

0. H. Greager

Walter Hibbard

Ronald Howard

K. Krauskopf

Joseph Lieberman

Le 1 and Jan Turk
Affiliation

Independent Consultant

Corporate Director, BMI

Global Marine, Inc.

Retired, Consultant

Independent Consultant

Virginia Polytechnic Institute

Stanford University

Stanford University

Nuclear Safety Associates

University of Texas 


\section{A-3}

\section{ONWI GEOLOGIC REVIEH GROUP}

\section{Name}

Arthur L. Bloom

William W. Hambleton

Irwin Remson

Howard P. Roșs

Charles I. Smith
Affiliation

Department of Geological Sciences

Cornell University

Kansas Geological Survey

Department of Applied Earth Sciences

Stanford University

University of Utah Research Institute

Department of Geology

The University of Texas at Arlington 
A-4

ONWI EARTH SCIENCES REVIEW GROUP

Name

George Ponder

Frank L. Parker

Neville G. W. Cook

John Bird.
Affiliation

Department of Civil Engineering Princeton University

Department of Environmental Engineering Vanderbilt University

Department of Materials Science and Mineral Engineering University of California, Berk ley

Geology Department Cornell University 


\section{ONWI PROGRAM REVIEW COMMITTEE}

Name

James M. Wall

Charlotte J. Toulowe

Sheldon E. Steinbach

James Porterfield

John O'Connor

Harry Kinn

L. Charles Hebel, Jr.

Kenneth I. Guscott

Hymer L. Friede 11, M.D.

Dorothy M. Ford

Yvonne Condell

William E. Benson

Thomas H. Langevin
Affiliation

Editor, The Christian Century

Citizen, Albuquerque, NM

American Council on Education.

American Farm Bureau Federation

University of Delaware

Citizen, Lawrenceville, NJ

Xerox Corporation

Citizen, Boston, MA

Case Western Reserve Hospital of Cleveland

Citizen, Whittier, CA

Moorehead State University

University of Hawait

Independent Consultant 


\section{BASALT WASTE ISOLATION PROGRAM REVIEW COMMITTEES}

Name

Affiliation

\section{Rock Mechanics}

John Handin

John Corwine

Bill Hustrulid

Neville Cook

Al Mathews

Donald Swanson

Howard Ross

Vaughn Livingston

Bill Twenhofel

Irwin Remson

Hydrology

\section{Geology}

Texas A\&M University

U. S. Bureau of Mines

Colorado School of Mines

University of California, Berkeley

Consultant

U. S. Geological Survey

University of Utah

State of Washington Department of Natural Resources

U. S. Geological Survey

Stanford University

U. S. Geological Survey

Vanderbilt University

State of Washington Department of Ecology

University of Illinois

Intera Environmental Consultants, Inc. 


\section{NEVADA NUCLEAR WASTE STORAGE INVESTIGATIONS TECHNICAL PEER REVIEWS}

Name

\section{Media Studies*}

William C. Luth

Sandia Laboratories

Richard V. Wyman

Paul R. Fenske

John Handin

James E. Russe11

Affiliation Vegas, NV)

Independent Consultant

Geology and Geophysics Dep artment

Texas A\&M University

Geophysics and Mining

Department of Engineering University of Nevada (Las

Engineering Department

Texas A\&M University

* Media Studies Technical Peer Review Held Apri1, 1979.

\section{Geological and Hydrological Studies*}

Richard V. Wyman

John Handin

Paul R. Fenske

Lawrence T. Larson

Pat A. Domenịco

Howard P. Ross
Department of Engineering University of Nevada

(Las Vegas, NV)

Geology and Geophysics

Department

Texas A\&M University

Independent Consu 1 tant

Mackay School of Mines University of Nevada (Reno, NV)

Department of Geology University of Illinois

University of Utah Research Institute

*Geological and Hydrological Studies Technical Peer Review held May, 1979. 
Name

Affiliation

\section{Spent Fuel Test-Climax*}

Richard V. Wyman

James

E. Russell

Lawrence T. Larson

John Handin

Neville G. W. Cook

William C. McClain

Pau 1 R. Fenske

* Spent Fuel Test Technical Peer Review held June, 1979.
Department of Engineering University of Nevada (Las Vegas, NV)

Geophysics and Mining

Engineering Department

Texas A\&M University

Mackay School of Mines University of Nevada (Reno, NV)

Geology and Geophysics Department

Texas A\&M University

Mining Engineering Department University. of California, Berkeley

RE/SPEC

Independent Consultant 


\section{A-9}

Name :

Affiliation

\section{Téctonics, Seismicity, Volcanism*}

George A. Thompson

Paul R. Fenske

John R. Wilbanks

Stanley A. Schumm

Alan Ryal1

Richard V. Wyman

Jerry M. Hoffer.

* Tectonics, Seismicity, Volcanism Technical Peer Review held July, 1979.
Independent Consultant

Independent Consultant

University of Nevada

(Las Vegas, NV)

Independent Consultant

Mackay School of Mines

Seismological Laboratory

University of Nevada

(Reno, NV)

Department of Engineering University of Nevada

(Las Vegas, NV)

University of Texas (EI PasO) 